\title{
A Comparison Between the Transpressional Plate Boundaries of South Island, New Zealand, and Southern California, USA: The Alpine and San Andreas Fault Systems
}

\author{
Gary S. Fuis ${ }^{1}$, Monica D. Kohler ${ }^{2}$, Martin Scherwath ${ }^{3,6}$, Uri ten Brink ${ }^{4}$, \\ Harm J.A. Van Avendonk ${ }^{5}$, and Janice M. Murphy ${ }^{1}$
}

\begin{abstract}
There are clear similarities in structure and tectonics between the Alpine Fault system (AF) of New Zealand's South Island and the San Andreas Fault system (SAF) of southern California, USA. Both systems are transpressional, with similar right slip and convergence rates, similar onset ages (for the current traces), and similar total offsets. There are also notable differences, including the dips of the faults and their plate-tectonic histories. The crustal structure surrounding the AF and SAF was investigated with active and passive seismic sources along transects known as South Island Geophysical Transect (SIGHT) and Los Angeles Region Seismic Experiment (LARSE), respectively. Along the SIGHT transects, the AF appears to dip moderately southeastward ( $\sim 50$ deg.), toward the Pacific plate (PAC), but along the LARSE transects, the SAF dips vertically to steeply northeastward toward the North American plate (NAM). Away from the LARSE transects, the dip of the SAF changes significantly. In both locations, a midcrustal decollement is observed that connects the plate-boundary fault to thrust faults farther south in the PAC. This decollement allows upper crust to escape collision laterally and vertically, but forces the lower crust to form crustal roots, reaching maximum depths of $44 \mathrm{~km}$ (South Island) and $36 \mathrm{~km}$ (southern California). In both locations, upper-mantle bodies of high $\mathrm{P}$ velocity are observed extending from near the Moho to more than $200-\mathrm{km}$ depth. These bodies appear to be confined to the PAC and to represent oblique downwelling of PAC mantle lithosphere along the plate boundaries.
\end{abstract}

${ }^{1}$ Earthquake Hazards Team, U.S. Geological Survey, Menlo Park, California.

${ }^{2}$ Center for Embedded Networked Sensing, University of California, Los Angeles, California.

${ }^{3}$ School of Earth Sciences, Victoria University of Wellington, Wellington, New Zealand.

${ }^{4}$ Coastal and Marine Geology Team, U.S. Geological Survey, Woods Hole, Massachusetts.

${ }^{5}$ Institute of Geophysics, University of Texas, Austin, Texas.

${ }^{6}$ Now at Leibniz Institute of Marine Sciences, IFM-GEOMAR, Kiel, Germany.

A Continental Plate Boundary: Tectonics at South Island, New Zealand Geophysical Monograph Series 175

Copyright 2007 by the American Geophysical Union. 10.1029/175GM16

\section{INTRODUCTION}

The South Island Geophysical Transect (SIGHT), on the South Island of New Zealand, and the Los Angeles Region Seismic Experiment (LARSE), in southern California, USA, were carried out to image and understand the lithospheric structure across two large and comparable right-lateral, transpressional fault systems, the Alpine and San Andreas Faults (AF and SAF, respectively; Figure 1). Although there are clear similarities between the two fault systems and their structural and tectonic settings, there are also notable differences. It was hoped at the outset of both experiments that similarities and differences between the two fault systems would manifest themselves and reveal the nature of the 

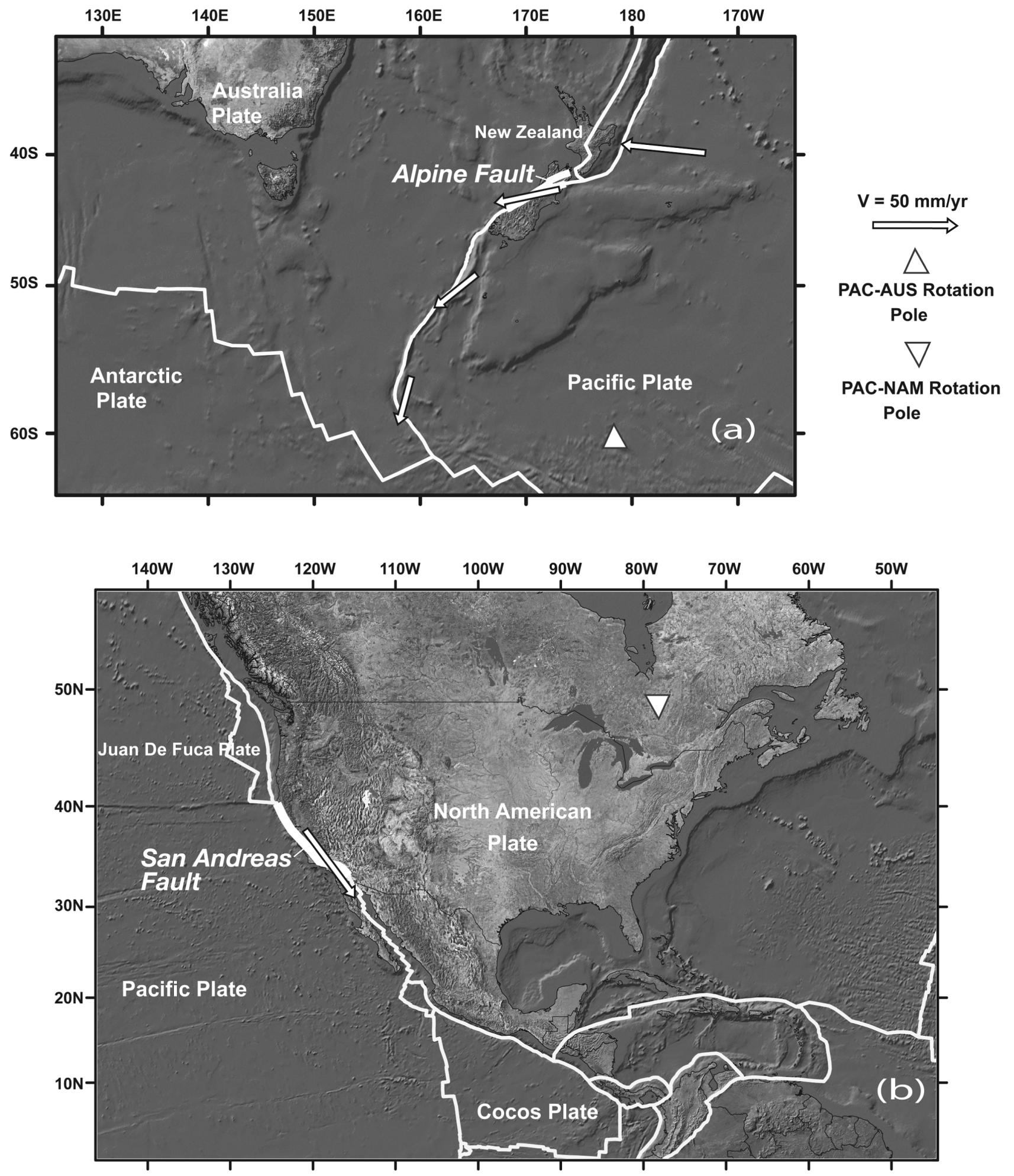

Figure 1. Shaded relief maps of (a) southwest Pacific Ocean and (b) North America, showing plate boundaries (white lines), poles of rotation (white triangles) for Pacific-Australian (PAC-AUS) plates and Pacific-North American (PAC-NAM) plates, and plate-motion vectors (white arrows) near Alpine and San Andreas Faults (heavy white lines). Ocean, dark gray; regions above sealevel, various shades of light gray. Color version of this figure is on CDROM which accompanies this volume. 

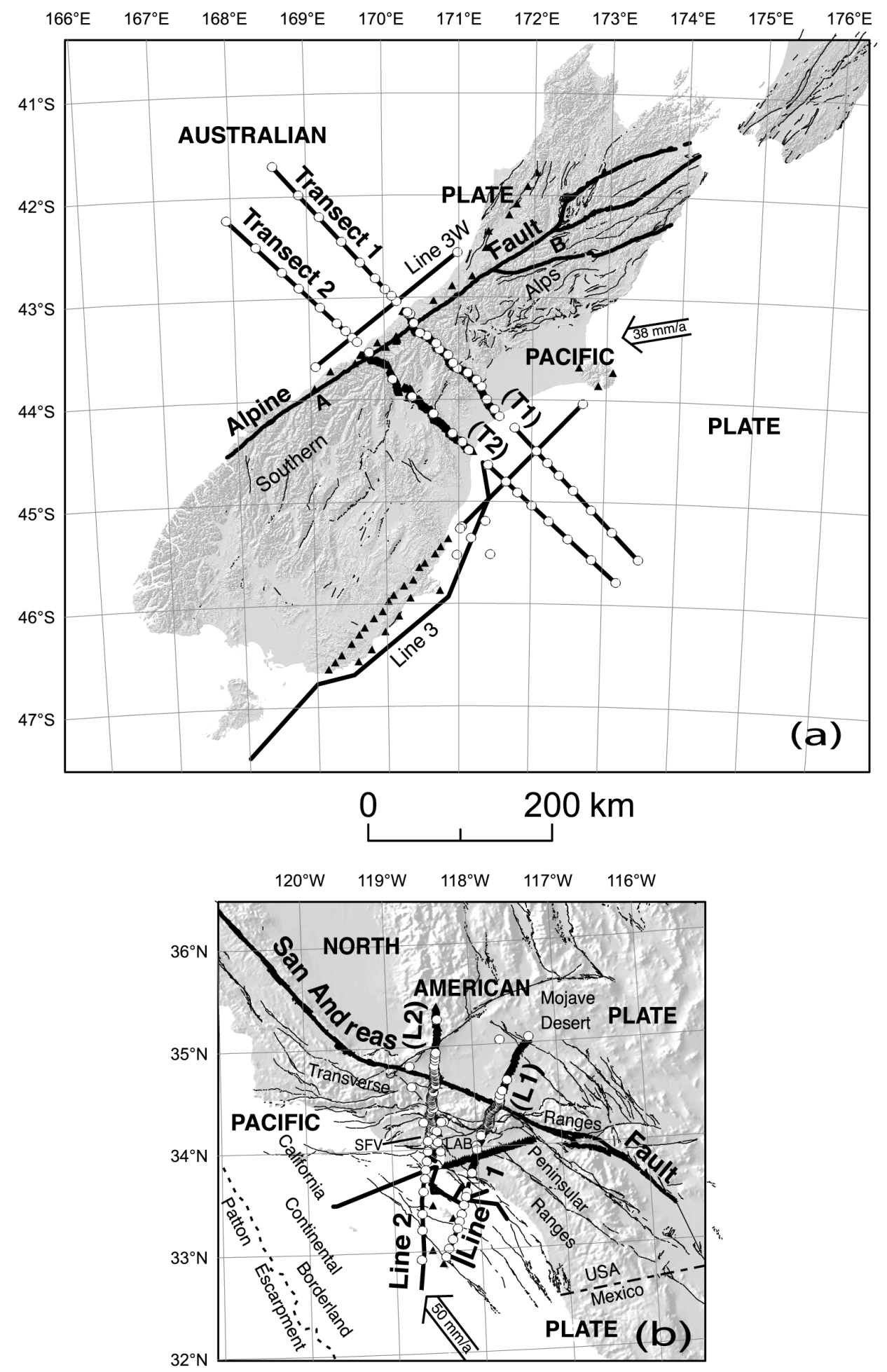

Figure 2. Shaded relief maps of (a) South Island of New Zealand and (b) southern California, USA, showing transects of South Island Geophysical Transect (SIGHT) and Los Angeles Region Seismic Experiment (LARSE). Black triangles, portable onshore seismographs; white-filled circles, shotpoints (onshore) and ocean-bottom seismographs (offshore); thin black lines, locations of airgun sources and towed streamers; heavy black lines, plate boundary faults (including Alpine Fault and its branches and San Andreas Fault); thin black lines, other Cenozoic faults. A,B outline central part of Alpine Fault studied by Sibson et al. [1979]. Pacific plate motion vectors shown in both (a) and (b) relative to Australian and North American plates, respectively, LAB, Los Angeles basin, SFV, San Fernando Valley. Color version of this figure is on CDROM which accompanies this volume. 
underlying geological processes in both locations. This hope has, to a large extent, been realized.

On South Island and in southern California, relatively detailed seismic profiles and complementary geophysical data were collected across the fault systems (Figure 2). SIGHT and LARSE, collected in the middle to late 1990's, included two transects each separated by distances of $50-70 \mathrm{~km}$, in order to obtain information on the three-dimensional nature of both fault systems. Both had offshore, offshore-onshore, and onshore active-source components [e.g., Davey et al., 1998, this volume; ten Brink et al., 2000; Fuis et al., 2001, 2003], as well as passive components [e.g., Kohler and EberhartPhillips, 2002; Kohler et al., 2003]. Both experiments produced models of seismic velocity and reflectivity that permit detailed comparison. These two fault systems may be the best studied transpressional plate boundaries to date.

\section{GENERAL SIMILARITIES BETWEEN THE ALPINE AND SAN ANDREAS FAULT SYSTEMS}

The AF and onshore part of the SAF systems originated more than $20 \mathrm{Ma}$ ago [22-26 Ma for the AF and $22 \mathrm{Ma}$ (onshore) to $28 \mathrm{Ma}$ (offshore) for the SAF; see Molnar et al., 1975; Carter and Norris, 1976; Kamp, 1986, for the AF, and Atwater, 1989; Atwater and Stock, 1998; Powell, 1993, for the SAF]. Both fault systems have similar total fault offsets of $450-480 \mathrm{~km}$, although the the onshore SAF has less offset in southern California [315 km; Powell, 1993]. The plate boundary regions in New Zealand and the western U.S. have both experienced additional deformation. In New Zealand, oroclinal bending, beginning as early as the Eocene, may account for $300 \mathrm{~km}$ of additional right-lateral deformation, although much debate has centered around the origin and timing of this oroclinal bending [see summary in Sutherland, 1999; Cox and Sutherland, this volume]. Extension and strike slip faulting inboard of the SAF, in the Basin and Range province, plus offset along older faults of the SAF system, beginning as early as $28 \mathrm{Ma}$, account for $600+\mathrm{km}$ of additional right-lateral deformation [Atwater and Stock, 1998]. Both fault systems changed from pure strike-slip or transtensional regimes to transpressional regimes at approximately similar times: $6.4 \mathrm{Ma}$ for the AF and 5-6 Ma for the SAF [see Walcott, 1998, for a summary of New Zealand; Powell, 1993; Oskin et al., 2001, for southern California]. Both the current traces of the AF and SAF have somewhat similar geodetic right-lateral slip rates of 35-37 mm/yr (AF) to $20-30+\mathrm{mm} / \mathrm{yr}$ (SAF) [see Beavan et al., 1999; this volume, for AF; Savage and Lisowski, 1998 (30+ mm/yr); Argus et al., 2005 (20 mm/yr), for SAF]. The geodetic compression rates across the regions are also similar, 10-11 mm/yr [Beavan et al., 1999, this volume, for AF; Argus et al., 2005, for SAF].
Total relative plate motion rates at the latitudes of South Island and southern California are $\sim 38 \mathrm{~mm} / \mathrm{yr}$ for PAC-AUS, and $\sim 50 \mathrm{~mm} / \mathrm{yr}$ for PAC-NAM. Note that the AF takes up the majority (60-80 percent) of the PAC-AUS plate motion, whereas the SAF takes up a smaller fraction (40-70 percent) of the PAC-NAM plate motion.

\section{GENERAL DISSIMILARITIES BETWEEN THE ALPINE AND SAN ANDREAS FAULT SYSTEMS.}

The plate-tectonic histories differ for the AF and SAF. The AF originated as the transform boundary between the PAC and AUS at 22-26 Ma. The AF has had a single primary strand until the last few Ma and currently connects two oppositely dipping subduction zones [see summary in Walcott, 1998; Cox and Sutherland, this volume]. The current pole of rotation between the two plates is a little over 15 degrees away from the AF. It has migrated southward to a position where it puts the two plates into transpression across the AF (Figure 1a). The nearness of the current pole of rotation leads to compression across the fault that changes along strike. In contrast, the history of the SAF system has involved the interactions of three plates, the Farallon, Pacific, and North American plates (Figure 1b). The Farallon plate was subducting beneath most of the western USA until $28 \mathrm{Ma}$, when a segment of the PAC-Farallon spreading ridge approached the NAM trench in the region of northern Mexico, and a transform fault was created connecting two oppositely migrating triple junctions [Atwater, 1989]. (The largest remnants of the Farallon plate are the Juan de Fuca and Cocos plates (Figure 1b).) This transform fault migrated landward, gradually adding fragments of NAM to PAC, until it jumped ashore creating the onshore SAF system. Baja California was the most recent addition of NAM to PAC, which occurred between 6.4 and $4.7 \mathrm{Ma}$ [Oskin et al., 2001]. When the PAC-NAM plate boundary jumped inland in southern California to the current Gulf of California, the "Big Bend" in the SAF was created, and transpression replaced transtension.

The dips of the two faults appear to differ. Based on foliations in outcrops within the AF zone, Sibson et al. [1979] provide evidence that, in its central part (A to B, Figure 2a), including the vicinity of the SIGHT transects, the fault dips consistently 40 to 50 degrees southeastward. Gravity driven nappes flatten the fault zone to gentle dips in many places, but these places were avoided by Sibson et al. [1979] in determining the consistent moderate southeast dip. A steeper dip of 50-70 degrees was determined by Woodward [1979] from gravity, with the AF connecting to the steep northwest side of a crustal root (see below). In contrast, the SAF has a steep northeast to vertical dip in the vicinity of the LARSE 
lines, based on seismic results and potential-field studies (see below). To the northwest, however, it reverses dip to moderately southwestward [Griscom and Jachens, 1990]. To the southeast, it dips moderately northeastward [Jones et al., 1986; Griscom and Jachens, 1990; Fuis et al., 2007], although local dip reversals with depth ("wedge tectonics") have been modeled in one place from potential-field data [Langenheim et al., 2005].

Rainfall amounts and erosion patterns differ strongly between South Island and southern California. On South Island rainfall and erosion are highly asymmetric, with the most rainfall (3 $\mathrm{m} / \mathrm{yr})$ and erosion occurring on the northwest side of the Southern Alps. The southeast side of the Southern Alps gets $0.65 \mathrm{~m} / \mathrm{yr}$ rainfall, by contrast. Erosion removes much of the rock being uplifted on the northwest side of the Southern Alps, along the Alpine fault [see Koons, 1990], keeping elevations low and exposing rocks uplifted from mid-crustal levels [see Sibson et al., 1979]. In contrast, the rainfall/erosion pattern in southern California is only moderately asymmetric, but the rainfall is six to ten times lower than on South Island. The Transverse Ranges still contain preserved sedimentary basins dating from the Miocene and earlier, indicating much lesser uplift and erosion than on South Island.

\section{COMPARISON BETWEEN CRUSTAL STRUCTURES ACROSS THE ALPINE AND SAN ANDREAS FAULTS}

SIGHT, which includes transects T1 and T2, and LARSE, which includes Lines 1 and 2 (L1 and L2), involved offshore and onshore recording of airguns and onshore recording of explosions (Figure 2). The length of each SIGHT transect was $\sim 600 \mathrm{~km}$ (onshore $\sim 150 \mathrm{~km}$; offshore $\sim 450 \mathrm{~km}$ ), and the length of the LARSE transects ranged from 350-400 (onshore $\sim 150 \mathrm{~km}$; offshore $\sim 200-250 \mathrm{~km}$ ). Onshore shotpoint and station spacing for SIGHT was $\sim 10-20 \mathrm{~km}$ and 300-400 $\mathrm{m}$, respectively, vs 1-25 km and 100-500 $\mathrm{m}$ for LARSE. Offshore recordings were much more extensive for SIGHT, because they could be collected on both sides of South Island. On all four transects, structures associated with the modern Alpine and San Andreas Fault systems are seen as well as structures associated with older continent-building events.

\section{Water Depth and Sedimentary Basins}

Water depths on the continental shelves offshore of South Island and southern California are up to $\sim 1.5 \mathrm{~km}$. Late Cretaceous to Cenozoic sedimentary basins offshore of South Island vary in thickness between AUS and PAC, with a common thickness range and a maximum thickness of 1-2 $\mathrm{km}$ and $4 \mathrm{~km}$, respectively, for AUS, and 2-3 km and $6 \mathrm{~km}$, respectively for PAC [Scherwath et al., 2003; van Avendonk et al., 2004; Plates 1a, 1b]. Cenozoic sedimentary basins offshore of southern California are typically shallow along the LARSE lines [0.5 km; Baher et al., 2005] but deepen toward the shore, reaching variable depths of 1.5 to $4 \mathrm{~km}$ [Wright, 1991] (Plates 1c, 1d). Onshore sedimentary basins, on the other hand, are shallower on South Island compared to southern California, at least in the vicinity of the transects discussed here. For example, onshore along T1 on South Island, Late Cretaceous to Cenozoic sedimentary and volcanic rocks reach maximum depths of $2.5-3 \mathrm{~km}$, on the southeast side of South Island (Plate 1a). Onshore along Line 1 in southern California, Cenozoic sedimentary and volcanic rocks thicken abruptly to as much as 10-km depth in the Los Angeles basin [Fuis et al., 2001; Plate 1d]. Onshore along Line 2 in southern California, these basins reach various maximum depths, ranging from $\sim 5 \mathrm{~km}$ in the San Fernando Valley to $\sim 3 \mathrm{~km}$ farther north [Fuis et al., 2005; Plate 1c].

\section{Basement and Lower Crust}

South Island. "Basement" is used here to refer to uppercrustal rocks having velocities in the approximate range of 5.0$6.5 \mathrm{~km} / \mathrm{s}$. "Lower crust" here refers to rocks having velocities in the approximate range of $6.5-7.5 \mathrm{~km} / \mathrm{s}$. On both transects $\mathrm{T} 1$ and $\mathrm{T} 2$ offshore of South Island, basement rocks reach depths ranging between 15 and $19 \mathrm{~km}$ on both AUS and PAC, but these depths increase to more than $20 \mathrm{~km}$ in the vicinity of the coast [Scherwath et al., 2003; van Avendonk et al., 2004; Plates 1a, 1b]. Onshore they deepen further to form the upper part of an asymmetrical crustal root, which has a steep side on the northwest and a gentle side on the southeast (Plates 1a, 1b). On both transects, basement velocity reaches slightly higher values on the PAC $(6.2-6.3 \mathrm{~km} / \mathrm{s})$ than on AUS $(6.0-$ $6.1 \mathrm{~km} / \mathrm{s})$. On both transects, a prominent zone of relatively low basement velocity $(5.8-6.0 \mathrm{~km} / \mathrm{s})$ is seen in the vicinity of the crustal root from near the surface to the lower crust (see discussion below). The base of basement rocks is constrained by intracrustal reflections (PiP) from the top of lower crust.

The AF is contained within the upper-crustal low-velocity zone, but unfortunately, its dip through the crust is uncertain. Surface outcrops of the fault near the SIGHT lines indicate a dip of 40-50 degrees southeastward [Sibson et al., 1979]. On $\mathrm{T} 2$, moderately southeast-dipping reflections are seen at midcrustal depths that are possibly related to the AF (Plate 1b). On a supplementary reflection profile along or near T2, Stern et al. (this volume) find steeply southeast-dipping reflections, which when migrated, suggest a 60 -degree dip for the AF at $\sim 15-$ $20 \mathrm{~km}$ depth and a listric shape, whereby the fault becomes subhorizontal between 30 - to $35-\mathrm{km}$ depth. Thus, the AF appears to flatten into a mid- to lower-crustal decollement (see below). 

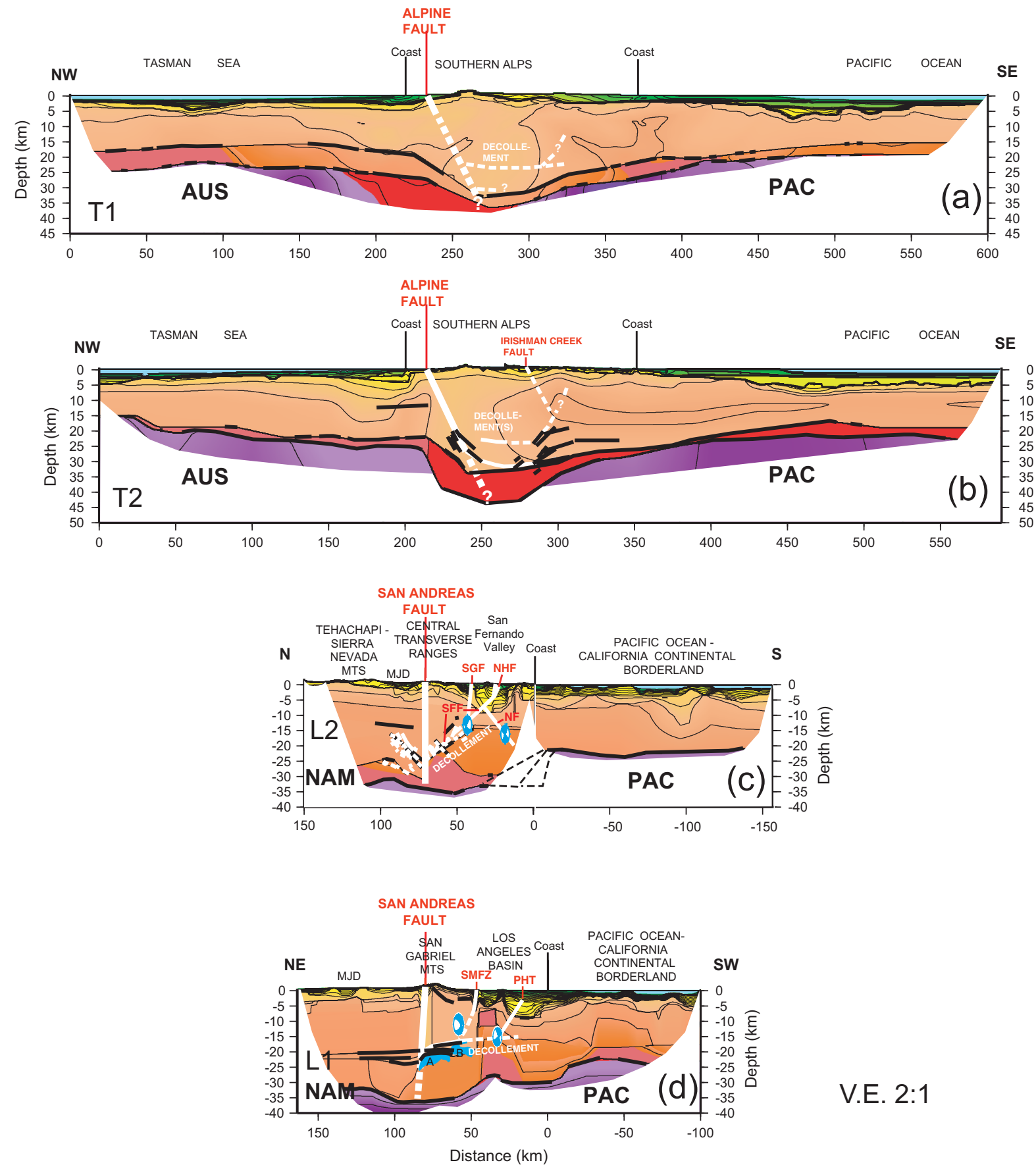

V.E. $2: 1$

VELOCITY (KM/S) 
Offshore of South Island, AUS lower crust is thicker on T1 $(5-7 \mathrm{~km})$ than on T2 $(0.5-2 \mathrm{~km})$, but PAC lower crust is similar on both transects (1-5 km) [Scherwath et al., 2003; van Avendonk et al., 2004; Plates 1a, 1b]. Onshore lower crust on T1 thins to $2-4 \mathrm{~km}$ at the base of the crustal root, but on T2, it thickens to 8-10 km within the root (Plates 1a, 1b). Velocity of the lower crust and its base (Moho) are constrained by Moho reflections (PmP). Moho depth (crustal thickness) is in the range of $25-28 \mathrm{~km}$ at both coasts on both $\mathrm{T} 1$ and $\mathrm{T} 2$. It is interesting to note that this same coastal crustal thickness is observed on both transects in southern California (see below; Plates 1c, 1d). Moho depth shoals seaward of the coast and deepens landward into the crustal root discussed above. The maximum crustal thickness at the root is $37 \mathrm{~km}$ on $\mathrm{T} 1$ and $44 \mathrm{~km}$ on T2; its relief is $\sim 10 \mathrm{~km}$ on T1 and $18 \mathrm{~km}$ on T2. On both T1 and T2, the maximum crustal thickness is located $\sim 15 \mathrm{~km}$ southeastward of the main topographic divide of the Southern Alps and $40 \mathrm{~km}$ southeastward of the AF.

Based on seismic velocities and crustal thicknesses, both of the two transects across South Island outside of the Southern Alps represent thin continental crust [see Meissner, 1986, for continental thicknesses; Christensen and Mooney, 1995, for continental velocities]. Beneath the Southern Alps, crustal thicknesses are in the normal range. At the northwest end of T2 (offshore), crustal thinning and an increase of sedimentary basin thickness probably represents a transition toward oceanic crust [Scherwath et al., 2003].

Southern California. Offshore of southern California, ten Brink et al. [2000] modeled basement on Line 1 extending to the Moho at $~ 20-\mathrm{km}$ depth. Baher et al. [2004, 2005] have modeled base- ment on this line extending to $\sim 17-18-\mathrm{km}$ depth, with a thin ( $\sim 5-\mathrm{km}$ thick) lower crust and a deeper Moho $(\sim 23 \mathrm{~km})$. Unlike South Island, there are no intracrustal reflections (PiP) to directly constrain the top of the lower crust. As Moho depth is directly correlated with thickness and velocity of the lower crust (or, alternatively, with average crustal velocity), the models of ten Brink et al. [2000] and Baher et al. [2004, 2005] can be regarded as alternate models. The model of Baher et al., however, is constrained by additional data, namely, onshore-offshore data, and we have chosen to show their model in Plate 1d. For Line 2, we have only the model of ten Brink et al. [2000], which we regard as preliminary, as onshore-offshore data can be used to better constrain this model now that the onshore model has been finalized [Fuis et al., 2005]. In any case, a large step or slope in Moho is required near the coast on this line [Plate 1c; see ten Brink et al., 2000].

Onshore in southern California, Line 1 is underlain by a three-part crust south of the San Gabriel Mountains (part of the Central Transverse Ranges), a two-part crust in the San Gabriel Mountains, and a one-part crust in the Mojave Desert, north of the SAF [Plate 1d; Fuis et al., 2001]. From the coast to the San Gabriel Mountains, the crust contains deep (5- to 10-km-deep) Cenozoic sedimentary basins, basement, and lower crust with a prominent intrusion or horst-like feature projecting upward to near the base of the sedimentary rocks in the northern Los Angeles basin (Plate $1 \mathrm{~d}$; intrusion/ horst-like feature is at $35-45 \mathrm{~km}$ in the model coordinate system). The San Gabriel Mountains are underlain by basement to $\sim 20-\mathrm{km}$ depth and lower crust to $36-\mathrm{km}$ depth. Basement consists of relatively high velocities $(6.2$ $\mathrm{km} / \mathrm{s}$ ) in the upper $5 \mathrm{~km}$ overlying relatively low velocities $(5.8-6.0 \mathrm{~km} / \mathrm{s})$ that extend to $20-\mathrm{km}$ depth. At the base of basement rocks, strong wide-angle reflections and a marked zone of bright near-vertical-incidence reflections are observed that appear to project gently upward and southward from the SAF to the 1987 M 5.9 Whittier Narrows earthquake hypocenter [features A and B, Plate 1d; Ryberg and Fuis, 1998; see discussion below]. North of the SAF, basement velocities $(<6.45 \mathrm{~km} / \mathrm{s})$ occur down to Moho depths of 32-36 km. Strong wide-angle reflections are seen at 2024-km depth in the Mojave Desert. A steeply north-dipping SAF (85 degrees) is interpreted from an offset in wide-angle reflectors (termination of reflective layer $\mathrm{A}$ ) at a point a few $\mathrm{km}$ north of the surface trace [Fuis et al., 2001]. Potentialfield studies, however, indicate a vertical dip [Langenheim, 1999]. The SAF is not associated with a wide upper-crustal low-velocity zone as on South Island, although on Line 1, a faint, poorly resolved, narrow $(\sim 5 \mathrm{~km})$ low-velocity zone extends to midcrustal levels (Plate 1d).

Plate 1. (opposite) Models of crust and uppermost mantle for (a) SIGHT T1 [van Avendonk et al., 2004], (b) SIGHT T2 [Scherwath et al., 2003], (c) LARSE Line 2 (L2) [ten Brink et al., 2000; Fuis et al., 2003, 2005], and (d) LARSE Line 1 (L1) [Fuis et al., 2001; Baher et al., 2004, 2005]. Heavy black lines, wide-angle reflectors; thin, dashed black lines in (c), alternate Moho geometries from ten Brink et al. [2000]. Heavy white lines, plate boundary faults, dashed where not clearly observed; thin white-line segments in (c), nearvertical-incidence reflectors. Blue beach balls in (c) and (d), focal mechanisms for M 5.8-6.7 earthquakes within $10 \mathrm{~km}$ of transects; far hemispheres displayed; vertically exaggerated along with rest of figure. Blue bodies A and B in (d), bright-layer reflections. AUS, Australian plate; PAC, Pacific plate; NAM, North American plate. Abbreviations in (c) and (d) MJD, Mojave Desert; NF, Northridge fault; NHF, Northridge Hills fault; PHT, Puente Hills thrust fault; SFF, San Fernando fault; SGF, San Gabriel fault; SMFZ, Sierra Madre fault zone. V.E. 2:1. 
Beneath Line 1, the Moho has several steps. It steps downward from 24 to $28 \mathrm{~km}$ near the coast, and from 28 to $36 \mathrm{~km}$ near the boundary between the Los Angeles basin and the San Gabriel Mountains. It steps upward again, from 36 to 32 $\mathrm{km}$ in the southern Mojave Desert. The latter two steps bound a crustal root that is approximately centered on the SAF, $\sim 6$ $\mathrm{km}$ north of the topographic high of the San Gabriel Mountains [Fuis et al., 2001; Baher et al., 2004]. The root has a relief of 4-8 km, smaller than the root on South Island. Kohler and Davis [1997] found that a crustal root with vertical relief of $\sim 10 \mathrm{~km}$, also centered below the SAF, explained LARSE teleseismic $\mathrm{P}$-wave travel-time residual observations.

Similar to onshore Line 1, onshore Line 2 [Plate 1c; Fuis et al., 2003, 2005] is underlain by a three-part crust south of the Central Transverse Ranges and a two-part crust in the Central Transverse Ranges. In the western Mojave Desert north of the SAF, it is underlain by a three-part crust, as opposed to the one-part crust of Line 1. From the coast to the Central Transverse Ranges, the crust contains moderately deep (3to 5-km-deep) Cenozoic sedimentary basins, basement, and lower crust. The Central Transverse Ranges are underlain by basement down to a north-dipping interface extending from the 1971 M 6.7 San Fernando earthquake hypocenter, at $\sim 13-\mathrm{km}$ depth, to the SAF at $25-\mathrm{km}$ depth. This interface and a fainter interface a few $\mathrm{km}$ above it bracket a nearvertical-incidence to wide-angle reflective zone. The western Mojave Desert is underlain by a moderately deep sedimentary basin $(3+\mathrm{km})$, basement, and a relatively thin lower crust. Basement contains a south-dipping, near-verticalincidence reflective zone that is symmetric to the reflective zone south of the SAF. A subvertical SAF appears to offset all layers above the Moho. Lower crust is much thicker south of the SAF and has a poorly constrained velocity. The Moho ranges in depth from $22 \mathrm{~km}$ just offshore [ten Brink et al., 2000] to $36 \mathrm{~km}$ beneath the Transverse Ranges, forming a crustal root with a relief of $5 \mathrm{~km}$ (north) to $14 \mathrm{~km}$ (south). The SAF is located toward the north side of this root.

Based on seismic velocities and thicknesses, both of the transects across southern California represent thin continental crust southwest of the crustal roots and normal continental crust elsewhere. The transition to PAC oceanic crust occurs approximately $150 \mathrm{~km}$ southwest of the offshore ends of the LARSE lines, at the Patton Escarpment (Figure 2b).

\section{UPPER-MANTLE VELOCITIES AND STRUCTURE}

\section{Observations and Models}

South Island. Owing to recordings at long offsets on the $\mathrm{T} 1$ and $\mathrm{T} 2$ transects and to recordings along cross lines, upper-mantle Pn velocities are relatively well resolved on
South Island. Along T1 and T2, mantle velocities are above $8.0 \mathrm{~km} / \mathrm{s}$ (as high as $8.2-8.3 \mathrm{~km} / \mathrm{s}$ ) everywhere except in a region beginning at the bottom of the crustal root (T1) or the north side of the crustal root (T2; no Pn coverage below the root) and extending northwestward $\sim 100 \mathrm{~km}$, where the velocity is as low as $7.8 \mathrm{~km} / \mathrm{s}$ [Scherwath et al., 2003; van Avendonk, 2004; Plates 1a, 1b]. Crossline results near the northwest and southeast coasts reveal Pn velocities of 8.2$8.6 \mathrm{~km} / \mathrm{s}$ [Scherwath et al., 2002; Melhuish et al., 2005] and 8.2 [Godfrey et al., 2001], respectively. The crossline near the northwest coast (Figure 2a, Line $3 \mathrm{~W}$ ) traverses the region of $7.8-\mathrm{km} / \mathrm{s}$ velocity on transects $\mathrm{T} 1$ and $\mathrm{T} 2$ and clearly indicates horizontal anisotropy in the upper mantle [Scherwath et al., 2002]. Thus, high Pn velocities are parallel to the AF. The cross line near the southeast coast (Figure 2a, Line 3 ), more than $200 \mathrm{~km}$ away from the plate boundary, agrees approximately with transects $\mathrm{T} 1$ and $\mathrm{T} 2$ in upper mantle velocity and indicates no significant horizontal anisotropy there [Godfrey et al., 2001; cf. Baldock and Stern, 2005].

Steeply traveling $\mathrm{P}$ waves from $\sim 40$ teleseisms recorded on South Island reveal a body of relatively high upper-mantle velocity (up to $3 \%$ higher than the average for South Island) that underlies most of South Island, except for a couple of regions on the southeast side of the island [Kohler and Eberhart-Phillips, 2002; Plate 2a]. In three dimensions, this body of relatively high velocity is elongate (nearly $600 \mathrm{~km}$ long), $100 \mathrm{~km}$ across, appears to cross the AF obliquely, and extends to depths of more than $200 \mathrm{~km}$. It extends the length of the AF and into the subduction zones on either end (Plate 2a). A cross section along T1 shows that this body is tabular and dips moderately northwestward ( $\sim 55$ degrees; Plate 3a, top); however, resolution tests for this region indicate that at least some of this northwestward dip is likely an artifact of raypaths used in the inversion (for example, a vertical test cylinder dips $\sim 80$ degrees north after inversion). At $45-\mathrm{km}$ depth, its northwest edge is located near the center of the crustal root. Similarly shaped tabular regions of relatively low velocity are seen both northwest and southeast of this high-velocity body. A cross section along T2 shows more complexity, with the high-velocity body being much wider and having both northwest- and southeastdipping legs (Plate 3a, bottom). At 50-km depth, the northwest boundary of the feature is located near the northwest edge of the crustal root.

In contrast to the results of Kohler and Eberhart-Phillips [2002], Stern et al. [2000] found from modeling three teleseisms that occurred inline with portable recorders on $\mathrm{T} 1$ and T2 that the upper-mantle high-velocity body is constrained to be nearly vertical, approximately $70 \mathrm{~km}$ wide, limited in depth extent (from $\sim 60$ - to $160-\mathrm{km}$ depth), having a maximum velocity of $8.5-8.6 \mathrm{~km} / \mathrm{s}$, and centered approximately 
FUIS ET AL. 315
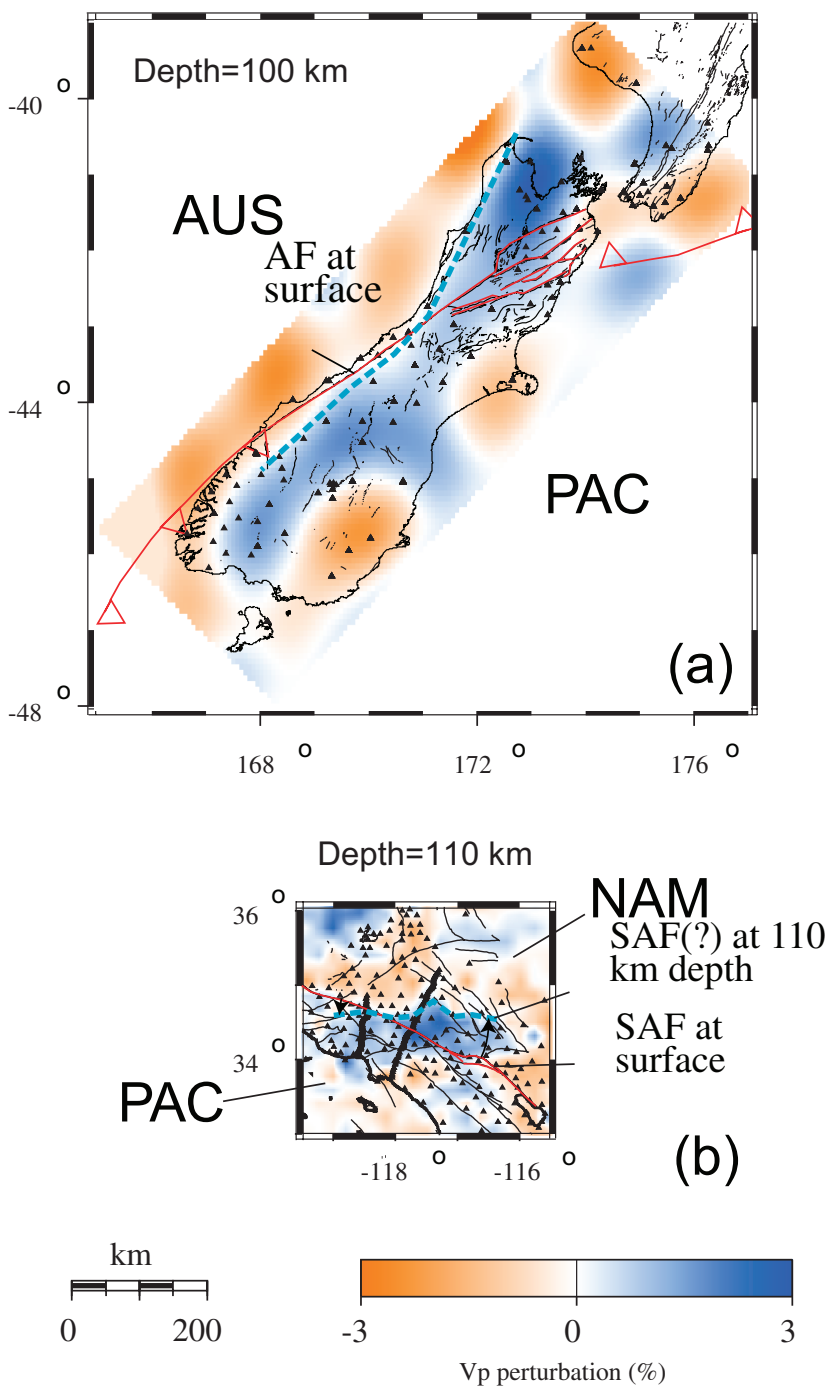

Plate 2. Horizontal slices of mantle for (a) South Island (100-km depth) and (b) southern California (110-km depth). Black triangles, seismographs that recorded teleseisms for mantle tomography; solid red lines, plate boundary faults (including Alpine Fault (AF) and its branches and San Andreas Fault (SAF)); red lines with teeth, subduction zones (teeth on upper plate); dashed cyan lines, northwest and north sides of high-velocity bodies (blue) at 100-, 110-km depth for (a), (b), respectively; thin black lines, other Cenozoic faults. (Note that all surface features, including AF and SAF, are projected downward 100 to $110 \mathrm{~km}$.) Zero on color scale is $8.3 \mathrm{~km} / \mathrm{s}$ at $100-\mathrm{km}$ depth for (a) and $8.1 \mathrm{~km} / \mathrm{s}$ at 110-km depth for (b). In southern California, geometric relationship can be established between SAF (red line) and north side of high-velocity body (dashed cyan line) that gives rise to apparent counterclockwise rotation of latter away from former (black rotation arrows; see text). On South Island, origin of similar apparent counterclockwise rotation is not as clear. 
beneath the crustal root. Instrument density was greater in the two-dimensional study of Stern et al. [2000; 2- to 4-km spacing] than in the three-dimensional study of Kohler and Eberhart-Phillips [2002; 20- to 100-km spacing], but only three inline earthquakes were used in the former study versus $\sim 40$ earthquakes from many azimuths in the latter. Differences between the two studies also stem in part from the fact that the three-dimensional study was an inverse model and, therefore, necessarily smooth, whereas the twodimensional study was a forward model, with relatively sharper boundaries. In our illustrations (Plate 3a), we show both models of the high-velocity body.

Southern California. In southern California, average Pn velocities determined from local earthquake sources are generally higher north and south of the Transverse Ranges (8.0 $8.2 \mathrm{~km} / \mathrm{s}$ ) than within the Transverse Ranges $(7.7-7.8 \mathrm{~km} / \mathrm{s}$ ) [Hearn, 1984], whether one considers anisotropy or not. From active sources on the LARSE transects, Pn is poorly resolved but seems to be less than or equal to about $8.0 \mathrm{~km} / \mathrm{s}$ everywhere. The azimuthal variation in Pn for the central part of southern California (Mojave Desert, Transverse Ranges, and Los Angeles basin) is quite striking [Hearn, 1984]. Hearn calculates that the fast direction is $\mathrm{N} 75 \mathrm{~W}$, approximately parallel to the strike of the SAF through the Transverse Ranges, and that anisotropy is $\sim 3-4 \%$. (A prior study of Pn anisotropy for approximately the same region [Vetter and Minster, 1981] found approximately the same value for anisotropy but a fast direction of $\mathrm{N} 50 \mathrm{~W}$, approximately parallel to the direction of relative motion between PAC and NAM.)

A number of authors have imaged or modeled a prominent high-velocity body in the upper mantle of southern California [Hadley and Kanamori, 1977; Raikes, 1980; Bird and Rosenstock, 1984; Humphreys et al., 1984; Sheffels and McNutt, 1986; Humphreys and Clayton, 1990; Humphreys and Hager, 1990; Kohler, 1999; Kohler et al., 2003]. The study of Kohler et al. [2003], which includes data from several hundred teleseisms recorded on portable deployments (2-km spacing) along the LARSE lines and on the permanent southern California array, provides the highest resolution image of this body to date (Plates $2 \mathrm{~b}, 3 \mathrm{~b}$ ). This body extends more than $250 \mathrm{~km}$ east-west through the Transverse Ranges and is somewhat narrower in plan view than the South Island body (Plate 2). Similar to the body on South Island, it appears to cross the plate boundary obliquely and extends to more than $200-\mathrm{km}$ depth. This body is $\sim 70-80 \mathrm{~km}$ wide at or near the Moho but broadens to 160 - to $240-\mathrm{km}$ width at a depth of $200 \mathrm{~km}$ (compare Plate 3b with Plate 3a). At 40-km depth on Line 1, the northeast edge of the feature is located at or near the projection of the north-dipping SAF to the Moho. It is irregular and split below $160-\mathrm{km}$ depth (similar to the fea- ture on T2), and the dips of the two components below 160 $\mathrm{km}$ are $\sim 80$ degrees and 55 degrees northward. The more steeply dipping component of the feature has approximately the same dip as the deep projection of the SAF. At $40-\mathrm{km}$ depth on Line 2, the northeast edge of the body is also at or near intersection of the SAF (here vertical) and the Moho. The north side of this feature also appears to be vertical.

In the cross sections along the LARSE lines (Plate $3 \mathrm{~b}$ ) and in cross sections across the SAF farther northwest and southeast [Fuis et al., 2006, 2007], the north side of the high-velocity body appears coplanar or at least continuous with the SAF. Both the SAF and the north side of the high-velocity body change dip along strike: in the northwest, the dip is moderately southwest; at the LARSE lines, it is steep; and in the southeast it is moderately northeast. Thus, the overall shape of a surface fitted to the SAF and the north side of the high-velocity body appears to be crudely propeller shaped. This geometry gives rise to the appearance in plan view that the north side of the high-velocity body crosses and is rotated counterclockwise from the surface trace of the SAF (Plate 2b, dashed cyan line). Although one sees a similar apparent plan-view geometry on South Island for the northwest side of the high-velocity body (Plate $2 \mathrm{a}$, dashed cyan line), the deep structure of the plate boundary beyond the vicinity of the SIGHT lines is less clear.

\section{Resolution}

Formal lateral resolution limits differ between South Island and southern California for the upper-mantle highvelocity bodies because of different station spacing and different inversion parameterizations. In southern California, station spacing ranges from 15 to $40 \mathrm{~km}$ in the central part of the network, although LARSE portable arrays were also used, where spacing was $2 \mathrm{~km}$. The mantle was gridded in 20 - by $20-\mathrm{km}$ blocks and the formal lateral resolution length-scale limit for the whole region is $\sim 40 \mathrm{~km}$. In checkerboard and vertical-cylinder tests, however, one observes near the LARSE lines that the inverted boundaries of the input checkerboard or vertical cylinders differ from input locations by generally less than 15-20 km (at depths of 40 to $200 \mathrm{~km}$ ), indicating good resolution at a length scale of 15-20 km. On South Island, station spacing for the permanent network averages $\sim 100 \mathrm{~km}$, but several portable arrays with denser station spacing were used. A two-dimensional Fourier series parameterization was used (on 40-km-thick layers) and the formal lateral resolution length-scale limit for the whole region is a bit over $100 \mathrm{~km}$. As for southern California, checkerboard and vertical-cylinder tests near the SIGHT lines indicate boundary displacements by the inversion of less than $\sim 20 \mathrm{~km}$ (at depths of 100 to $200 \mathrm{~km}$ ). As 

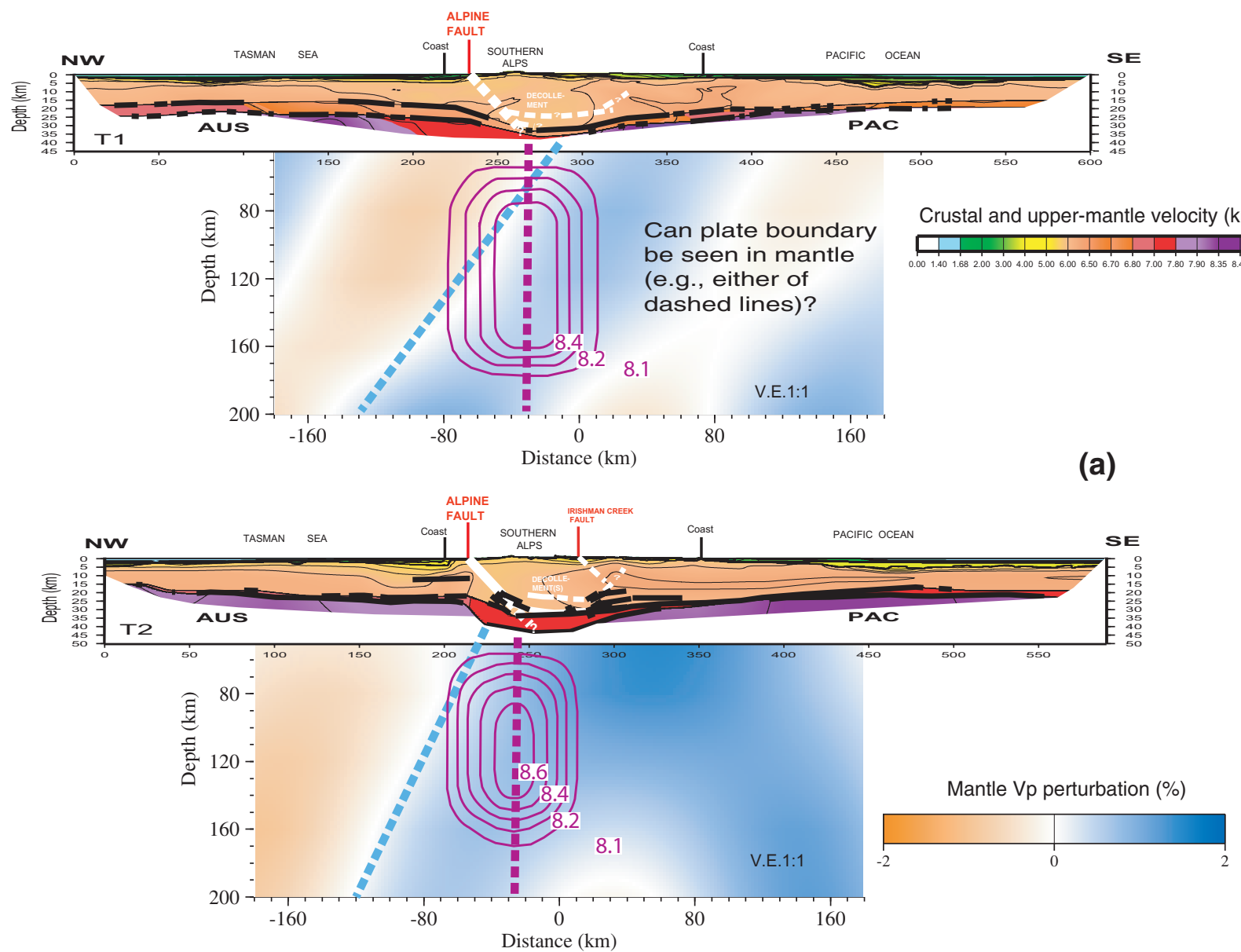

Crustal and upper-mantle velocity $(\mathrm{km} / \mathrm{s})$

Plate 3. (a) Crustal models from Plates 1a, 1b combined with vertical slices of mantle below each line. See Plate 1 for explanation of symbols in crust. In mantle, color scale is from Kohler and Eberhart-Phillips [2002]. Zero on color scale is $8.2 \mathrm{~km} / \mathrm{s}$ at $40-\mathrm{km}$ depth and $8.5 \mathrm{~km} / \mathrm{s}$ at 200-km depth. [For intermediate depths, refer to Kohler and Eberhart-Phillips, 2002]. Thin purple lines with P velocities (in $\mathrm{km} / \mathrm{s}$ ), velocity contours from Stern et al. [2000]; heavy cyan and purple dashed lines, our interpretations of northwest boundaries of highvelocity bodies in mantle from both studies above: cyan, Kohler and Eberhart-Phillips [2002], purple, Stern et al. [2000]. These dashed lines may or may not represent traces of plate boundary in mantle (see text). V.E. 1:1. (b) Crustal models from Plates 1c, 1d combined with vertical slices of mantle below each line. See Plate 1 for explanation of symbols and abbreviations in crust. In mantle, color scale is from Kohler et al. [2003]. Zero on color scale is $7.8 \mathrm{~km} / \mathrm{s}$ at $40-\mathrm{km}$ depth and $8.2 \mathrm{~km} / \mathrm{s}$ at 200-km depth. [For intermediate depths, refer to Kohler et al., 2003]. Heavy dashed cyan lines, our interpretations of north boundaries of high-velocity body; thin dashed white line in (b), projection of SAF below Moho. As in Plate 3a, heavy dashed cyan lines may or may not represent traces of plate boundary in mantle (see text). Abbreviations: CI, Santa Catalina Island; MJD, Mojave Desert, SMM, Santa Monica Mts.; SCI, San Clemente Island; SCR, San Clemente Ridge. V.E. 1:1. 

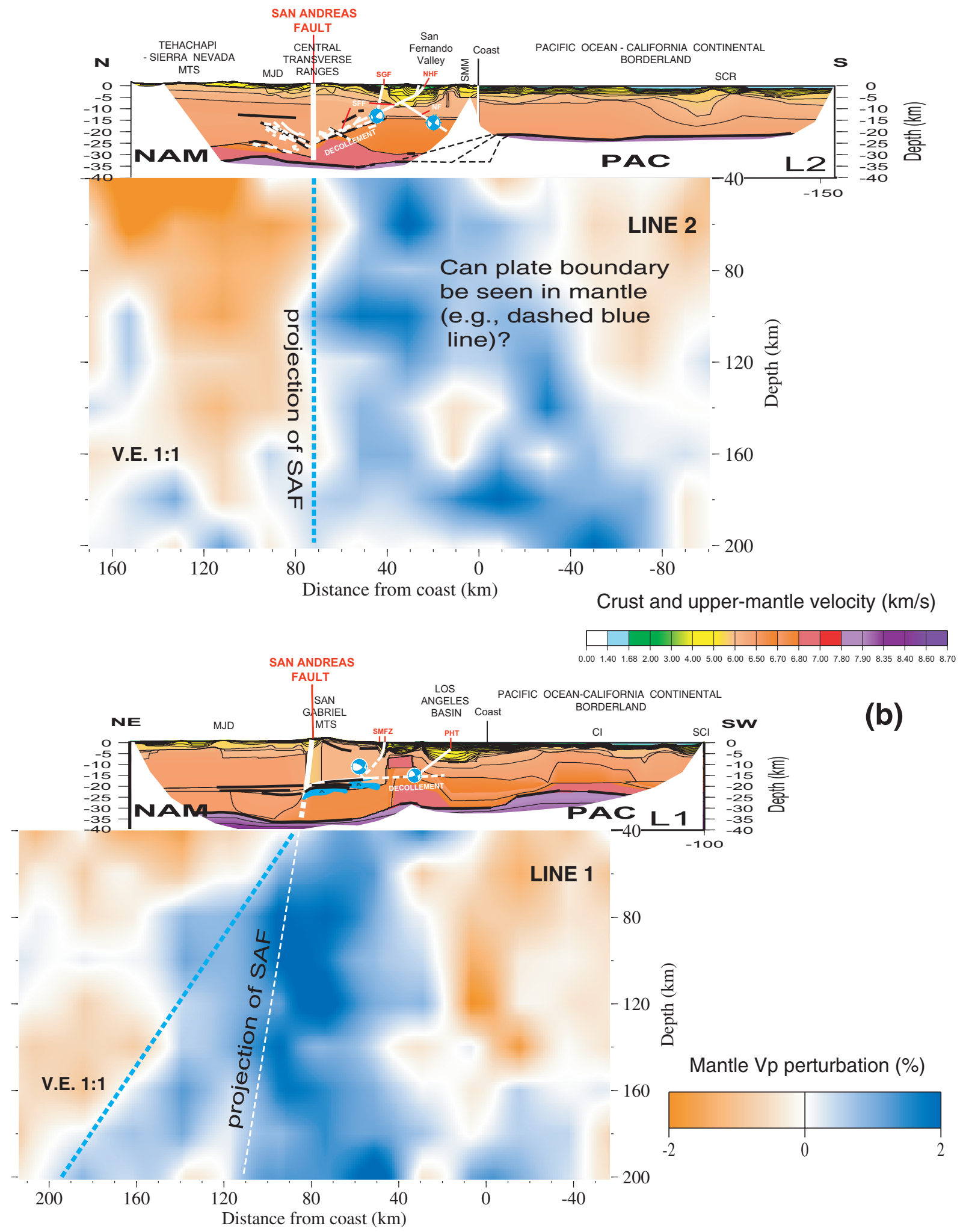

Plate 3. (Continued) 
noted above, however, the inversion tends to add a small northward dip to vertical features.

Vertical resolution limits for features imaged on South Island and in southern California are poorly known and are the subject of ongoing investigation. Steeply dipping imaging rays would be expected to smear features vertically. The fact that we see features dipping moderately in different directions, suggests that vertical smearing is not extreme.

\section{Interpretations of the Upper-Mantle High-Velocity Bodies}

Based on surface studies of Sibson et al. [1979], the AF dips moderately southeastward and would project to approximately the center of the crustal root (Plate 3a). A line fitted to the northwest side of the high-velocity upper-mantle body also projects to within $20-30 \mathrm{~km}$ of the center of the crustal root, but dips moderately northwestward. This geometry is suggestive of indentation of the PAC by the AUS (see below). Alternatively, the inferred plate boundary in the mantle may not connect with the crustal plate boundary, and there may be a zone of decoupling in the upper mantle to lower crust. In a third alternative, the inferred plate boundary in the mantle is vertical and lies within the high-velocity body of Stern et al. [2000] (Plate 3a).

The cross sections shown here for southern California (Plate $3 b)$, as well as cross sections across the SAF farther northwest and southeast [Fuis et al., 2006, 2007], show that the high-velocity upper-mantle body is south of the SAF where the SAF intersects or is projected to intersect the Moho. The high-velocity body is, therefore, on the PAC and receives no clear contribution from the NAM near the Moho. This body may, thus, have a different thermal structure or composition from lithosphere of the NAM. The north side of the body is continuous with the crustal plate boundary (SAF) everywhere, and is coplanar with it everywhere except on LARSE Line 1. Given this geometry, a likely interpretation of this body is that it is downwelling of PAC mantle lithosphere beneath the Transverse Ranges. Specifically, this body is downwelling of lithosphere of the Peninsular Ranges and Continental Borderland, which constitute the PAC south of the Transverse Ranges (see Figure 2). This downwelling also involves a significant component of right-lateral movement of the lithospheric mantle. The crust does not descend into the mantle with the lithosphere (as in oceanic subduction) but becomes decoupled at some point and remains behind in a crustal root.

Upper-mantle high-velocity bodies on South Island and in southern California may arise from differences between these bodies and the surrounding mantle in density or in orientation of velocity components in an anisotropic medium. Density differences may arise, in turn, from thermal or compositional differences [see e.g., Humphreys and
Hager, 1990]. At this point, it is not possible to eliminate any of these possibilities with certainty, although an origin from anisotropy alone seems unlikely. In both locations, it appears likely that lithospheric mantle of the PAC is downwelling obliquely along the plate boundary. In both places, downwelling of lithospheric mantle is likely characterized by a slight density difference between lithospheric mantle of the PAC and the opposing plates caused by thermal or compositional differences, or both.

Models of high-velocity bodies in the upper mantle of continental orogens can be divided into at least 2 classes, one class based on Rayleigh-Taylor density instability, and one class based on subduction of one slab of lithosphere beneath another [see Pysklywec et al., 2000]. In Rayleigh-Taylor instability, a denser layer of upper-mantle lithosphere downwells unstably ("drips") into a less dense asthenosphere. Two characteristics of Rayleigh-Taylor models are that the drips they produce in symmetric starting models are symmetric, contributed from the plates on either side of the point of initiation, and they are visible downward from the base of the lithosphere but not from the base of the crust [see e.g., Houseman et al., 1981, 2000]. Subduction involves thrusting of one plate of lithosphere beneath another, followed by gravitational instability that results from penetration of the underthrust plate into the less dense asthenosphere. Two characteristics of subduction models are that the subducted slab is contributed primarily by one plate, and the geometry is asymmetric with respect to the point of initiation [see e.g., Beaumont and Quinlan, 1994; Pysklywec et al., 2000]. These two classes of models can represent end members, given the broad spectrum of choices for convergence rates and rheological parameters for the various layers involved [crust, mantle lithosphere, asthenosphere; Pysklywec et al., 2000].

Rayleigh-Taylor models. The models of Stern et al. [2000] for South Island and Houseman et al. [2000] for southern California are Rayleigh-Taylor models. In the model of Stern et al. [2000], plate convergence is postulated to cause depression of isotherms beneath some point of initiation. A high-velocity upper-mantle body develops gradually with depth as colder material in the center of the downwelling isotherms acquires a velocity contrast with hotter material on either side. Houseman et al. [2000] numerically simulate viscous flow in a lithospheric drip with the characteristics of the southern California body. Although they show a drip appearing only from the base of the lithosphere, in reality, the single layer they model as lithospheric mantle would likely have a temperature gradient, and downward flow of isotherms would create a drip that would become gradually visible with depth beneath the Moho. One might calculate that a 3\% contrast 
320 COMPARISON OF ALPINE AND SAN ANDREAS FAULT SYSTEMS
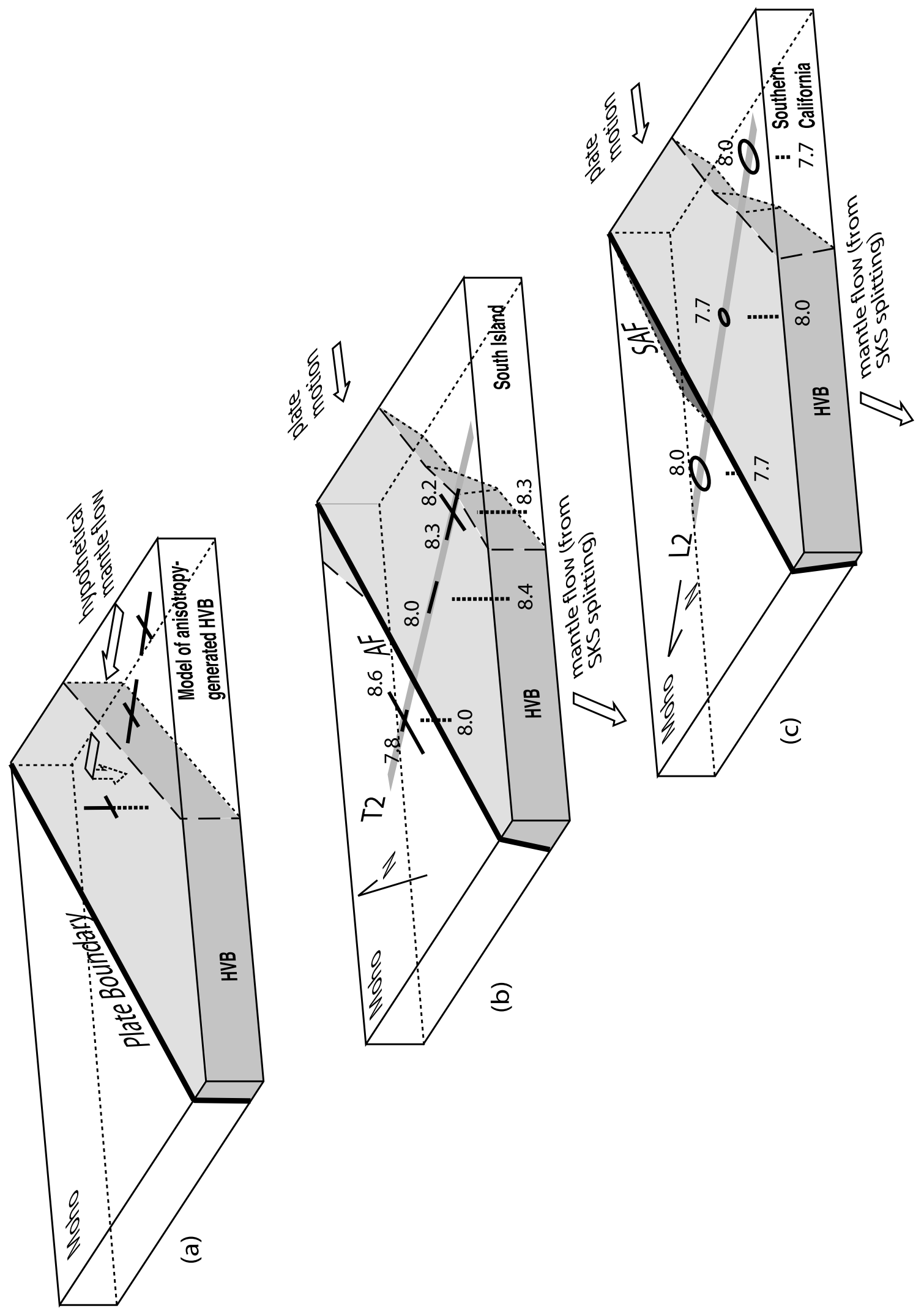
in velocity, such as shown in Plates 2, 3, would be acquired at approximately $50 \mathrm{~km}$ below the Moho, assuming an average mantle geotherm of $13 \mathrm{deg}$. C./km [Williams, 1996; for southern California], an adiabatic temperature gradient of $3 \mathrm{deg}$. C./km [Lachenbruch and Sass, 1980], and a P- velocity/temperature relationship of $-0.5 \mathrm{~km} / \mathrm{s} / \mathrm{deg}$. C. [Creager and Jordan, 1986]. One important feature of the Houseman et al. model is return upflow on the side of the drip, or convection, that serves to thin the lithospheric layer above and to enhance the thermal/density contrast of the drip to a somewhat shallower depth. In an attempt to simulate the asymmetric topography in southern California (high mountains only on the PAC), Billen and Houseman [2004] introduced a density contrast across the SAF and moved the point of drip initiation (shear weakening caused by strikeslip faulting) to a point south of the SAF, reasoning that older strands of the SAF are located in this region. They succeed in producing a drip south of the SAF, as we observe, but they start with equal contributions from the PAC and NAM.

Subduction models. The models of Pysklywec et al. [2000] demonstrate the varying influence of convergence rate and gravitational instability in the process of subduction. These models involve a relatively weak plastic crust, a relatively stiff plastic upper sublayer within the lithospheric mantle, a viscous lower sublayer within the lithospheric mantle, and an asthenosphere with a lower viscosity than the lower lithospheric layer. Some of their models [Figures 2, 4, and 5 of Pysklywec et al., 2000] match qualitatively the observations/inferences one might make from our Plate $3 b$, namely, an upper-mantle body of relatively high density that begins near the Mohos of the PAC and NAM, extends to $250+\mathrm{km}$, and is chiefly on the PAC (with no to minimal contribution from the NAM). In these models, no significant amount of crust descends into the mantle, although a crustal root is formed. On the other hand, a model dominated by gravitational instability (where convergence is reduced to zero after initial underthrusting; their Figure 3), does not match the features of our Plate $3 b$ as closely-for example, the drip is relatively too thin.

Anisotropic models. Anisotropy may play a part in the observation of upper-mantle high-velocity bodies. For example, one might imagine the fast axis of olivine grains aligned with flow in the mantle [see summary in Fuchs, 1977], which might be horizontal and perpendicular to an orogen on either side of the orogen but which might rotate to vertical in a downwelling beneath the orogen (Figure 3a). Thus, steeply traveling imaging rays from teleseisms would image a highvelocity body beneath the orogen that owed its existence to nothing more than an anisotropy rotation. What is actually observed both on South Island and in southern California, however, is that, where a fast direction is defined in the mantle from Pn studies, it is parallel to the plate boundaries (and parallel to the orogens) and cannot be simply flipped downward by a component of mantle flow perpendicular to the plate boundary (Figures 3b, 3c). (Note that velocities in Figures $3 b, 3 c$ do not necessarily represent the true velocity components of an anisotropic medium; these velocities were not determined at exactly the same points and are the results of independent studies. For example, we do not know for certain that the vertical velocities from the tomographic studies apply to the uppermost mantle where the Pn results apply, given the likelihood of vertical smearing in the tomographic modeling. At best, the velocities shown in Figures 3b, 3c are estimates of the three components of an anisotropic velocity.) Nevertheless, both high-velocity bodies and the mantle on either side appear to be at least in part anisotropic.

Splitting of SKS phases results from anisotropy (for horizontal vibration directions) at some unknown location(s) along the long path of SKS from the Earth's core to the surface [see e.g., Savage, 1999]. For both South Island and southern California, the fast direction of SKS is on average approximately parallel to the long axes of the high-velocity bodies: NE-SW on South Island and E-W in southern California [for South Island, see Savage et al., this volume, and discussion in Scherwath et al., 2002; for southern

Figure 3. (opposite) Schematic diagrams for (a) hypothetical generation of a high-velocity upper-mantle body (HVB) from simple rotation of anisotropic velocity components, (b) observed anisotropy on South Island compared to boundaries of observed HVB, platemotion vector (with respect to AUS), and mantle-flow vector (inferred from SKS splitting), (c) observed anisotropy in southern California similar to (b); plate-motion vector with respect to NAM. Note change in north arrow from (b) to (c). Top of blocks, Moho; heavy lines, plate boundaries; moderately heavy lines for (b), schematic Pn velocity components with attached values in $\mathrm{km} / \mathrm{s}$ from Scherwath et al. [2003], van Avendonk et al. [2004], and Godfrey et al., [2001]; moderately heavy ellipses for (c), schematic Pn velocity components from Hearn [1984] with long axes labeled with values of fast component, in km/s; moderately heavy dotted lines in (b) and (c), teleseismic mantle velocities from Kohler and Eberhart-Phillips [2002] (b) and Kohler et al. [2003] (c). Note that vertical components of velocity in (b) and (c) are not connected to horizontal, or Pn, components; it is not clear that these components were measured at same points as Pn components, namely in uppermost mantle (see text). 


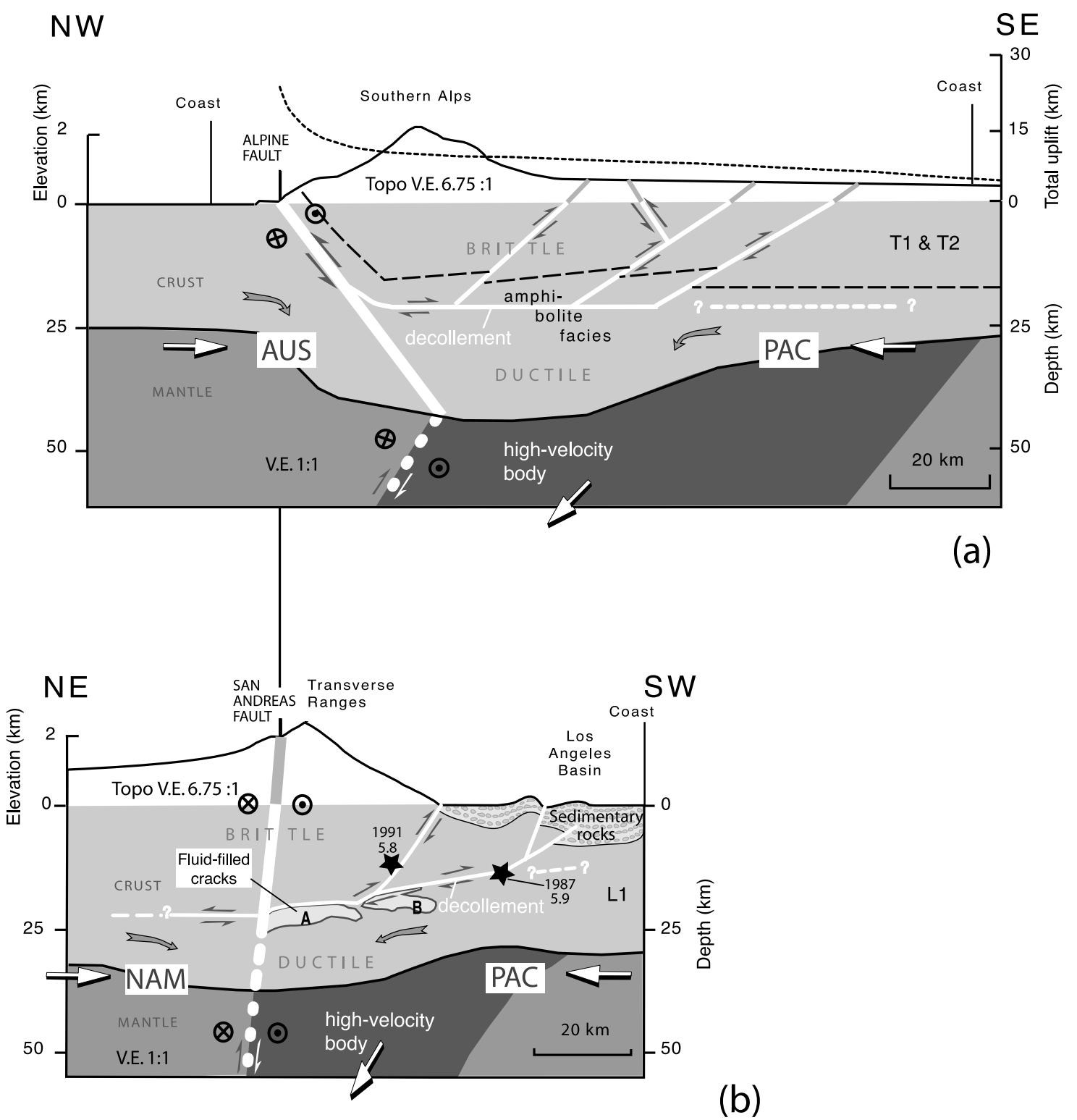

Figure 4. (a) Schematic diagram of tectonics of South Island along transects T1 and T2, adapted from Norris et al. [1990]. Light gray, crust; medium gray, relatively low-velocity mantle; dark gray, relatively high-velocity mantle. Heavy white line, Alpine Fault; heavy dotted line, interpreted plate boundary in mantle; thin white lines, other active faults (with relative-motion arrows); dashed black line, top of amphibolite-facies rocks (datum for fault offsets); curved arrows, rock motions for lower crust; large white arrows, relative plate-motion components in plane of section. (Note that motion along plate boundary in crust and mantle is primarily strike slip (circle with $\mathrm{x}$, motion away from viewer; circle with dot, motion toward viewer), with a component of compression (large white arrows-see above)). AUS is interpreted to indent PAC along AF and shear zone in mantle. Compression leads to formation of decollement separating brittle upper crust from ductile lower crust. Above decollement, rock travels through orogen, undergoing deformation on both sides of Southern Alps, with erosion removing most of uplifted rock, especially on northwest (see uplift scale on right). Below decollement, ductile rock has no escape and accumulates in crustal root. Note that decollement on South Island might be a broad zone, based on thickness of mylonite zone exposed along AF [Sibson et al., 1979] and width of observed reflective zone [Stern et al., this volume]. Topography exaggerated by 6.75; region below sealevel not vertically exaggerated. (b) Schematic diagram of tectonics of southern California along Line 1 (L1), adapted from Fuis et al. [2001]. For symbols and shading see caption for Figure 4a. Black stars, large earthquakes (magnitudes and dates attached); very light gray patches with black outlines, bright reflective zones A and B (see Plate 1d). Fluid-lubricated decollement is interpreted to ascend gently southwestward from bright reflective zone A near SAF. Above decollement, brittle upper crust imbricates along thrust and reverse faults. Below decollement, lower crust flows toward SAF (curved arrows in lower crust) and forms crustal root. Color version of this figure is on CDROM which accompanies this volume. 
California, see Polet and Kanamori, 2002]. The fast directions and delays between slow and fast directions are independent of whether the observation is made inside or outside the footprints of the high-velocity bodies. From this last observation, it would appear that the high-velocity bodies do not significantly perturb the overall S-wave anisotropy of the mantle for horizontal vibration directions, and thus do not owe their visibility to anisotropy, at least in those directions.

Other models. Bird and Rosenstock's [1984] analysis of the kinematics of surface fault movement in southern California requires downwelling of the mantle lithosphere along the oblique segment of the SAF. In their Figure 5, they infer a propeller-shaped lithospheric mantle downwelling that is remarkably similar to that observed. They also predict a decollement at the Moho in the vicinity of the SAF, but their model allows no decollements within the crust, as we actually observe.

Sheffels and McNutt [1986] modeled the gravity and topography of the vicinity of the Transverse Ranges by using two elastic lithospheric plates of different thicknesses and rigidities. The southern plate (Peninsular Ranges, Los Angeles basin, and Continental Borderland) is modeled as a thin, weak plate subducting beneath a thicker, stronger plate beneath the Transverse Ranges and Mojave Desert. The high-velocity upper-mantle body imparts a terminal force and bending moment to the southern plate, but its northern boundary is traced to a subduction zone (plate break) at the southern margin of the Transverse Ranges rather than to the SAF, as observed, The SAF is located within their strong elastic plate in the Central and Western Transverse Ranges and is not a primary discontinuity in the mechanics of the modeled subduction.

A few authors have suggested that the high-velocity upper-mantle body of southern California may be a fragment of oceanic lithosphere, such as the Monterey subplate of the Farallon plate [Humphreys, 1995; Atwater and Stock, 1998], and we also entertained such an idea [Fuis et al., 2006]. The Monterey plate was captured by the PAC at $\sim 19 \mathrm{Ma}$, and, as it moved northward with the PAC, its position beneath the western Peninsular Ranges caused break-away and clockwise rotation of an outboard fragment of the Peninsular Ranges, which is currently found in the western Transverse Ranges [Nicholson et al., 1994]. The plate boundary jumped landward at this time, presumably to the eastern side of the Monterey plate, or to some deep juncture in that plate. The plate boundary inferred at $\sim 19 \mathrm{Ma}$ is the San FrancisquitoFenner-Clemens Well fault [Powell, 1993]. This fault is deformed and offset by younger traces of the SAF, including the modern trace. The geometric link between the upper-mantle high-velocity body and the current trace of the SAF strongly suggests that this body formed no earlier than $\sim 6 \mathrm{Ma}$.

\section{TECTONICS}

A schematic cross section of central South Island by Norris et al. [1990; their Figure 4b], was constructed prior to the deep seismic imaging of SIGHT but remains a very useful interpretation (Figure $4 \mathrm{a}$ ). The fact that the highestgrade metamorphic rocks exposed along the AF represent a crustal depth of no more than $20-25 \mathrm{~km}$, in spite of the large component of convergence across the AF (now known to be $\sim 90 \mathrm{~km}$ ) led them to include a decollement at $20-\mathrm{km}$ depth beneath the Southern Alps, merging with the AF to the northwest. Above the decollement and AF, rock in the actively deforming Southern Alps is interpreted to move upward and northward to become exposed and eroded along the AF. The models of critical-wedge mechanics [e.g., Davis et al., 1984] led them to connect active thrust faulting southeast of the AF with this decollement. Using the gravity results of Woodward [1979], they hypothesized that lower crustal rock was accumulating in a crustal root centered southeast of the crest of the Southern Alps, as is seen most dramatically on T2 (Plate 1b). Stern et al. (this volume) provide some support for this tectonic model. They observe a curved reflective zone beneath the Southern Alps that they interpret as a decollement connecting northwestward with a (listric) AF. The subhorizontal part of this reflective zone is, however, deeper (30-35 km deep) than the decollement interpreted by Norris et al. [1990].

A very similar schematic diagram of deformation of the crust in southern California was constructed by Fuis et al. [2001; their Figure 3]. In this diagram, the SAF, unlike the AF, dips steeply, but it is connected to a mid-crustal decollement similar to the inferred decollement on South Island, that, in turn, connects upward to active thrust faults located southeastward in the Los Angeles region (Figure 4b). This decollement is clearly imaged on the LARSE lines as highly reflective zones, including a near-vertical-incidence "bright reflective layer" on Line 1 [Ryberg and Fuis, 1998; Plate 1d, blue bodies A and B]. Because of the highly reflective character of the southern California decollement, it is interpreted to be lubricated by fluids that are perhaps injected cyclicly into the brittle fault zones above the decollement in the manner described by Sibson [1992].

On both South Island and in southern California, crustal deformation is largely one-sided and largely within the PAC. In both cases, the upper crust behaves as a collection of brittle blocks that escape the collision zone upwardly and laterally. The lower crust, on the other hand, with no place to escape (at least in the central areas of both regions), thickens 
to produce a crustal root. In both cases, volumes of the crustal roots appear consistent with estimated total convergence [Godfrey et al., 2002; Henrys et al., 2004].

On both South Island and in southern California, mantle lithosphere of the PAC appears to be obliquely downwelling along the plate boundary. On South Island, the northwest side of this downwelling dips northwest and may be a zone of oblique shear that connects at or near the Moho to the crustal plate boundary (AF) which dips in the opposite direction. This geometry is suggestive of indentation of the PAC by the AUS (Figure 4a). Alternatives are also possible (see above). In southern California, the north side of this downwelling is approximately co-planar with, or at least continuous with, the crustal plate boundary (SAF), and would, thus, appear to constitute a zone of oblique shear between the PAC and NAM (Figure 4b). On both South Island and in southern California, downwelling may be modeled by strike slip plus a combination of thrusting of PAC mantle lithosphere beneath the opposing plates (AUS and NAM) and gravitational instability, although other models are possible.

\section{SUMMARY OF LITHOSPHERIC STRUCTURE AND TECTONICS}

The seismic images across the AF on South Island and the SAF in southern California reveal features of the plate boundary in both locations.

1. On South Island, the upper crust $(5.4-6.3 \mathrm{~km} / \mathrm{s})$ contains a prominent, wide $(50 \mathrm{~km})$ zone of low velocity $(5.8-6.0 \mathrm{~km} / \mathrm{s})$ beneath the Southern Alps that extends from near the surface to mid-crustal levels. The AF is contained within this zone. Surface outcrops of the fault near T1 and T2 indicate a dip $\sim 50$ degrees southeastward. On or near T2, migrated reflections are interpreted to represent a listric AF dipping $\sim 60$ degrees southeastward at $15-20 \mathrm{~km}$ depth and flattening into a decollement at 30 - to $35-\mathrm{km}$ depth. In southern California, in contrast, the SAF near Lines 1 and 2 dips steeply northward (85-90 degrees), based on seismic results and is associated with low velocities only near the surface, although on Line 1 , a faint, poorly resolved, narrow $(\sim 5 \mathrm{~km}) \mathrm{LVZ}$ extends to midcrustal levels. The SAF is indirectly more visible than the AF because it terminates strong mid-crustal reflective zones associated with interpreted mid-crustal decollements.

2 . On South Island, lower crust $(6.5-7.0 \mathrm{~km} / \mathrm{s})$ is relatively thin $(1-10 \mathrm{~km})$. On T1 it is thicker on AUS $(\sim 7 \mathrm{~km})$ than on PAC $(<5 \mathrm{~km})$ and it thins within a crustal root beneath the Southern Alps to 2- to 4-km thickness. On T2 the reverse is true, where it is thicker on PAC $(1-5 \mathrm{~km})$ than on AUS $(0.5-2 \mathrm{~km})$ and it thickens within a crustal root to $10-\mathrm{km}$ thickness. The top of lower crust on South Island is in most places marked by wide-angle reflections. In southern Califor- nia, lower crust $(6.6-6.9 \mathrm{~km} / \mathrm{s})$ is moderately thick on PAC $(5-20 \mathrm{~km})$ but non-existent to thin on NAM ( $0 \mathrm{~km}$, Line 1; 5 $\mathrm{km}$, Line 2). Beneath the Transverse Ranges, the top of the lower crust is marked by strong near-vertical-incidence to wide-angle reflections, that originate at the SAF and extend southward and upward in the PAC, terminating at, or projecting to, the hypocenters of significant recent earthquakes (1971 M 6.7 San Fernando and 1987 M 5.9 Whittier Narrows earthquakes). These reflections are believed to represent one or more fluid-lubricated decollements that connect upward to active thrust faults along the southern margin of the Transverse Ranges.

3. On South Island, the Moho is depressed beneath the Southern Alps to maximum depths ranging from 37 to 44 $\mathrm{km}$. This crustal root ranges in width from $85-95 \mathrm{~km}$ and is asymmetric, with its steepest side on the northwest side of the island. Northwest of the root, the Moho is $25 \mathrm{~km}$ deep, and on the southeast side of the root, $\sim 30 \mathrm{~km}$ deep. The maximum relief on this root ranges from $10 \mathrm{~km}$ (T1) to $18 \mathrm{~km}$ (T2). The surface trace of the AF is above the northwest edge of the crustal root, but if the fault dips moderately southeastward, it may project to the center of the crustal root at its maximum depth. In southern California, the Moho is depressed beneath the Transverse Ranges to a maximum depth on both Lines 1 and 2 of $36 \mathrm{~km}$. These roots are somewhat narrower than the South Island roots and have somewhat lesser reliefs (Line 1, maximum of $8 \mathrm{~km}$; Line 2, maximum of $14 \mathrm{~km}$ ). Like the South Island roots, they are approximately centered on the deep projection of the plateboundary fault.

4. On South Island and in southern California, a midcrustal decollement is inferred from reflectivity that connects the plate-boundary fault to thrust faults farther south in the PAC. This decollement allows upper crust to escape the collision zone laterally and vertically, but forces the lower crust to form a crustal root.

5. On South Island and in southern California, uppermantle bodies of high $\mathrm{P}$ velocity are observed extending from near the Moho to more than 200-km depth. On South Island the north side of the upper-mantle body dips moderately northwestward, although other dips are allowable. The AF is inferred to dip oppositely (see above), and may (or may not) join the north side of the mantle body at the Moho. If the AF and north side of the mantle body represent the plate boundary, then the AUS would appear to indent the PAC. In southern California, the north side of the body is coplanar or at least continuous with the SAF or its projection to the Moho. The SAF and the north side of the body change dip along strike and have a crude propeller shape.

6. Both on South Island and in southern California, the mantle bodies are inferred to represent oblique downwelling 
of PAC mantle lithosphere along the plate boundaries. This process may be modeled by strike slip plus a combination of underthrusting of the PAC mantle lithosphere beneath opposing plates (AUS and NAM) and ensuing gravitational instability, although other models are possible.

Acknowledgments. This paper benefited greatly from discussions with many people, although the interpretations we present are not necessarily consensus interpretations. These persons include (alphabetically) Peter Bird, Glenn Biasi, Paul Davis, Kevin Furlong, Greg Houseman, Gene Humphreys, Ray Ingersoll, Craig Jones, Art Lachenbruch, Vicki Langenheim, Pat McCrory, Craig Nicholson, Mike Oskin, Tom Parsons, Fred Pollitz, Bob Powell, Dan Scheirer, Tim Stern, Joann Stock, Bill Stuart, Colin Williams, Charley Wilson, Doug Wilson, Bob Yeats, and George Zandt. We thank John Hole, Simon Cox, Fred Davey, Fred Pollitz, and Donna Eberhart-Phillips for helpful reviews of earlier drafts of this paper. J. Luke Blair and Marco Ticci are primarily responsible for Figures 1 and 2. Funding for SIGHT and LARSE came mostly from the U.S. National Science Foundation with contributions from the New Zealand Foundation for Research Science and Technology, the U.S. Geological Survey, and the Southern California Earthquake Center.

\section{REFERENCES}

Argus, D. F., M. B. Heflin, G. Peltzer, F. Crampe, and F. H. Webb (2005), Interseismic strain accumulation and anthropogenic motion in metropolitan Los Angeles, J. Geophys. Res., 110, B04401.

Atwater, T. (1989), Plate tectonic history of the northeast Pacific and western North America, in The Geology of North America, Vol. N: The Eastern Pacific Ocean and Hawaii, edited by E. L. Winterer, D. M. Hussong, and R. W. Decker, Geological Society of America, Boulder, CO, pp. 21-72.

Atwater, T., and J. Stock (1998), Pacific-North America plate tectonics of the Neogene southwestern United States: an update, Int. Geol. Rev., 40, 375-402.

Baher, S., G. Fuis, C. Wilson, V. Langenheim, and J. Murphy (2004), The onshore-offshore LARSE I transect: San Clemente Island to the Mojave Desert-crustal blocks and the Moho: EOS Trans. AGU, 85, F1416.

Baher, S., G. Fuis, R, Sliter, and W. Normark (2005), Upper-crustal structure of the Inner Continental Borderland near Long Beach, California, Bull. Seismol. Soc. Am., 95, 1957-1969.

Baldock, G., and T. Stern (2005), Width of mantle deformation across a continental transform: evidence from upper mantle $(\mathrm{Pn})$ seismic anisotropy measurements, Geology, 33, 741-744.

Beaumont, C., and G. Quinlan (1994), A geodynamic framework for interpreting crustal scale seismic reflectivity patterns in compressional orogens, Geophys. J. Int., 116, 754-783.

Beavan, J., M. Moore, C. Pearson, M. Henderson, B. Parsons, G. Blick, S. Bourne, P. England, R. I. Walcott, and K. Hodgkinson (1999), Crustal deformation during 1994-1998 due to oblique continental collision in the central Southern Alps, New Zealand, and implications for seismic potential of the Alpine fault, J. Geophys. Res., 104, 25,233-25,255.

Beavan, J., S. Ellis, L. Wallace, and P. Denys (this volume), Kinematic constraints from GPS on oblique convergence of the Pacific and Australian Plates, Central South Island, New Zealand.

Billen, M. I., and G. A. Houseman (2004), Lithospheric instability in obliquely convergent margins: San Gabriel Mountains, southern California, J. Geophys. Res., 109, B01404.

Bird, P., and R. W., Rosenstock (1984), Kinematics of present crust and mantle flow in southern California, Geol. Soc. Am. Bull., 95, 946-957.

Carter, R. M., and R. J. Norris (1976), Cainozoic history of southern New Zealand; an accord between geological observations and plate tectonic predictions, Earth Planet. Sci. Lett., 31, 85-94.

Christensen, N. I., and W. Mooney (1995), Seismic velocity structure and composition of the continental crust: a global review, $J$. Geophys. Res., 100, 9761-9788.

Cox, S. C., and R. Sutherland (this volume), Regional geological framework of South Island, New Zealand, and its significance for understanding the active plate boundary.

Creager, K. C., and T. H. Jordan (1986), Slab penetration into the lower mantle beneath the Mariana and other island arcs of the Northwest Pacific, J. Geophys. Res., 91, 3573-3589.

Davis, D., J. Suppe, and F. A. Dahlen (1984), Mechanics of foldand-thrust belts and accretionary prisms, J. Geophys. Res., 88, $1153-1172$.

Davey, F. J., D. Eberhart-Phillips, M. Kohler, S. Bannister, G. Caldwell, S. Henrys, M. Scherwath, and H. van Avendonk (this volume), Geophysical structure of the Southern Alps orogen, South Island, New Zealand.

Davey, F. J., et al. (1998), Preliminary results from a geophysical study across a modern, continent-continent collisional plate boundary - the Southern Alps, Tectonophysics, 288, 221-235.

Fuchs, K. (1977), Seismic anisotropy of the subcrustal lithosphere as evidence for dynamical processes in the upper mantle, Geophys. J. R. Astron. Soc., 49, 167-179.

Fuis, G. S., R. W. Clayton, P. M. Davis, T. Ryberg, W. J. Lutter, D. A. Okaya, E. Hauksson, C. Prodehl, J. M. Murphy, M. L. Benthien, S. A. Baher, M. D. Kohler, K Thygesen, G.Simila, and G. R. Keller (2003), Fault systems of the 1971 San Fernando and 1994 Northridge earthquakes, southern California: relocated aftershocks and seismic images from LARSE II, Geology, 31, 171-174.

Fuis, G., M. Kohler, M. Scherwath, U. ten Brink, and H. van Avendonk (2006), A comparison between the transpressional plate boundaries of the South Island, New Zealand, and southern California, USA, Seismol. Soc. Am., Res. Lett., 77, 200.

Fuis, G. S., V. E. Langenheim, D. S. Scheirer, and M. D. Kohler (2007), The San Andreas Fault in southern California is almost nowhere vertical-Implications for tectonics, shaking hazards, and geodetic modeling, EarthScope National Meeting, Monterey, California, p. 18

Fuis, G. S., J. M. Murphy, S. Baher, T. Ryberg, M. D. Kohler, and D. A. Okaya (2005), Lithospheric refraction/reflection/ teleseismic model of LARSE Line 2: thrusting of the Santa Monica Mountains-San Fernando Valley block beneath the 
central Transverse Ranges, southern California, EOS Trans. AGU, 86(52), Fall Meet. Suppl., Abstract S41A-0971.

Fuis, G. S., T. Ryberg, N. J. Godfrey, D. A. Okaya, and J. M. Murphy (2001), Crustal structure and tectonics from the Los Angeles basin to the Mojave Desert, southern California, Geology, 29, 15-18.

Godfrey, N. J., F. Davey, T. A. Stern, and D.Okaya (2001), Crustal structure and thermal anomalies of the Dunedin Region, South Island, New Zealand, J. Geophys. Res., 106, 30,835-30,848.

Godfrey, N. J., G. S. Fuis, V. Langenheim, D. A. Okaya, and T. M. Brocher (2002), Lower crustal deformation beneath the central Transverse Ranges, southern California: results from the Los Angeles Region Seismic Experiment, J. Geophys. Res., 107, B7, ETG 8-1-8-19.

Griscom, A., and R. C. Jachens (1990), Crustal and lithospheric structure from gravity and magnetic studies, in The San Andreas Fault System, edited by R. E. Wallace, U.S. Geological Professional Survey Paper 1515, 239-260.

Hadley, D. and H. Kanamori (1977), Recent seismicity in the San Fernando region and tectonics in the west-central Transverse Ranges, California, Bull. Seismol. Soc. Am., 68, 1449-1457.

Hearn, T. (1984), Pn travel times in southern California, J. Geophys. Res., 89, (B3), 1843-1855.

Henrys, S. A., D. J. Woodward, D. Okaya, and J. Yu (2004), Mapping the Moho beneath the Southern Alps continent-continent collision, New Zealand, using wide-angle reflections, Geophys. Res. Lett., 31(17), L17602.

Houseman, G. A., D. P. McKenzie, and P. Molnar (1981), Convective instability of a thickened boundary layer and its relevance for the thermal evolution of continental convergent belts, J. Geophys. Res., 86, 6115-6132.

Houseman, G. A., E. A. Neil, and M. D. Kohler (2000), Lithospheric instability beneath the Transverse Ranges of California, J. Geophys. Res., 105(B7), 16,237-16,250.

Humphreys, E. D. (1995), Post-Laramide removal of the Farallon slab, western United States, Geology, 23, 987-990.

Humphreys, E. D., and Clayton, R. W. (1990), Tomographic image of the southern California mantle, J. Geophys. Res., 95, B11, $19,725-19,746$

Humphreys, E. D., R. W. Clayton, and B. H. Hager (1984), A tomographic image of mantle structure beneath southern California, Geophys. Res. Lett., 11, 7, 625-627.

Humphreys, E. D., and B. H. Hager (1990), A kinematic model for the recent development of southern California crust and upper mantle, J. Geophys. Res., 95(B11), 19,747-19,762.

Jones, L. M., L. K. Hutton, D. D. Given, and C. R. Allen (1986), The North Palm Springs, California, earthquake sequence of July 1986, Bull. Seismol. Soc. Am., 76, 1830-1837.

Kamp, P. J. J. (1986), The mid-Cenozoic Challenger Rift System of western New Zealand and its implications for the age of Alpine fault inception, Geol. Soc. Am. Bull., 97, 255-281.

Kohler, M. D. (1999), Lithospheric deformation beneath the San Gabriel Mountains in the southern California Transverse Ranges, J. Geophys. Res., 104, 15,025-15,041.

Kohler, M. D., and P. M. Davis (1997), Crustal thickness variations in southern California from Los Angeles Region Seismic Experi- ment passive phase teleseismic travel times, Bull. Seismol. Soc. Am., 87, 1330-1344.

Kohler, M. D., and D. Eberhart-Phillips (2002), Three-dimensional lithospheric structure below the New Zealand Southern Alps, $J$. Geophys. Res., 107(B10), ESE 6-1-6-15.

Kohler, M. D., H. Magistrale, and R. W. Clayton (2003), Mantle heterogeneities and the SCEC Reference Three-Dimensional Seismic Velocity Model Version 3, Bull. Seismol. Soc. Am., 93, 2, 757-774.

Koons, P. O. (1990), Two-sided orogen: collision and erosion from the sandbox to the Southern Alps, New Zealand, Geology, 18, 679-682.

Lachenbruch, A. H., and J. H. Sass (1980), Heat flow and energetics of the San Andreas fault zone, J. Geophys. Res., 85, 6185-6222.

Langenheim, V. E. (1999), Gravity and aeromagnetic models along the Los Angeles Region Seismic Experiment (Line 1), California, U.S. Geological Survey Open-File Report 99-388, 22 pp.

Langenheim, V. E., R. C. Jachens, J. C. Matti, E. Hauksson, D. M. Morton, and A Christensen (2005), Geophysical evidence for wedging in the San Gorgonio Pass structural knot, southern San Andreas fault zone, southern California, Geol. Soc. Am. Bull., $117,1554-1572$

Meissner, R. (1986), The Continental Crust-A Geophysical Approach, Academic Press, San Diego, CA.

Melhuish, A., W. S. Holbrook, F. Davey, D. A. Okaya, and T. Stern (2005), Crustal and upper mantle seismic structure of the Australian plate, South Island, New Zealand, Tectonophysics, 395, 113-135.

Molnar, P., T. Atwater, J. Mammerickx, and S. M. Smith (1975), Magnetic anomalies, bathymetry and the tectonic evolution of the South Pacific since the late Cretaceous, Geophys. J. R. Astron. Soc., 40, 383-420.

Nicholson, C., C. C. Sorlien, T. Atwater, J. C. Crowell, and B. P. Luyendyk (1994), Microplate capture, rotation of the western Transverse Ranges, and initiation of the San Andreas transform as a low-angle fault system, Geology, 22, 491-495.

Norris, R. J., P. O. Koons, and A. F. Cooper (1990), The obliquelyconvergent plate boundary in the South Island of New Zealand: implications for ancient collision zones, J. Struct. Geol., 12, 5/6, 715-725.

Oskin, M., J. Stock, and A. Martin-Barajas (2001), Rapid localization of the Pacific-North America plate motion in the Gulf of California, Geology, 29, 459-462.

Polet, J., and H. Kanamori (2002), Anisotropy beneath California: shear wave splitting measurements using a dense broadband array, Geophys. J. Int., 149, 313-327.

Powell, R. E. (1993), Balanced palinspastic resonstruction of prelate Cenozoic paleogeology, southern California: geologic and kinematic constraints on evolution of the San Andreas fault system, Boulder Colo., Geol. Soc. Am. Mem., 178, 1-106.

Pysklywec, R. N., C. Beaumont, and P. Fullsack (2000), Modeling the behavior of the continental mantle lithosphere during plate convergence, Geology, 28, 655-658.

Raikes, S. A. (1980), Regional variations in upper mantle structure beneath southern California, Geophys. J. R. Astron. Soc., $63,187-216$ 
Ryberg, T., and G. S. Fuis (1998), The San Gabriel Mountains bright reflective zone: possible evidence of young mid-crustal thrust faulting in southern California, Tectonophysics, 286, $31-46$.

Savage, J. C., and M. Lisowski (1998), Viscoelastic coupling model of the San Andreas Fault along the big bend, southern California, J. Geophys. Res., 103, 7281-7292.

Savage, M. K. (1999), Seismic anisotropy and mantle deformation: what have we learned from shear wave splitting?, Rev. Geophys., 37, 65-106.

Savage, M., M. Duclos, and K. Marson-Pidgeon (this volume), Seismic Anisotropy in the South Island, New Zealand.

Scherwath, M., T. Stern, F. Davey, and D. Okaya (2003), Lithospheric structure across oblique continental collision in New Zealand from wide-angle P wave modeling, J. Geophys. Res., 108, B12, 2566.

Scherwath, M., T. Stern, A. Melhuish, and P. Molnar (2002), Pn anisotropy and distributed upper mantle deformation associated with a continental transform fault, Geophys. Res. Lett., 29, 8.

Sheffels, B., and M. McNutt (1986), Role of subsurface loads and regional compensation in the isostatic balance of the Transverse Ranges, California: evidence for intracontinental subduction, $J$ Geophys. Res., 91, 6419-6431.

Sibson, R. H. (1992), Implications of fault valve behavior for rupture nucleation and recurrence, Tectonophysics, 211, 283-293.

Sibson, R. H., S. H. White, and B. K. Atkinson (1979), Fault rock distribution and structure within the Alpine Fault Zone: a preliminary account, in The Origin of the Southern Alps, R. Soc. N. Z. Bull., vol. 18, edited by R. I. Walcott and M. M. Creswell, pp. 55-65.

Stern, T., P. Molnar, D. Okaya, and D. Eberhart-Phillips (2000), Teleseismic $\mathrm{P}$ wave delays and modes of shortening the mantle lithosphere beneath South Island, New Zealand, J. Geophys. Res., 105(B9), 21,615-21,631.

Sutherland, R. (1999), Cenozoic bending of New Zealand basement terranes and Alpine fault displacement: a brief review, $N$. Z. Geol. Geophys., 42, 295-301. ten Brink, U. S., J.Zhang, T. M. Brocher, D. A. Okaya, K. D. Klitgord, and G. S. Fuis (2000), Geophysical evidence for the evolution of the California Inner Continental Borderland as a metamorphic core complex, J. Geophys. Res., 105, 5835-5857.

Van Avendonk, H. J. A., W. S. Holbrook, D. Okaya, J. K. Austin, F. Davey, and T. Stern (2004), Continental crust under compression: a seismic refraction study of South Island Geophysical Transect I, South Island, New Zealand, J. Geophys. Res., 109, B06302.

Vetter, U., and J.-B. Minster (1981), Pn velocity anisotropy in southern California, Bull. Seismol. Soc. Am., 71(5), 1511-1530.

Walcott, R. I. (1998), Modes of oblique compression: late Cenozoic tectonics of the South Island of New Zealand, Rev. Geophys., 36(1), 1-26.

Williams, C. F. (1996), Temperature and the seismic/aseismic transition; observations from the 1992 Landers earthquake, Geophys. Res. Lett., 23, 2029-2032.

Woodward, D. J. (1979), The crustal structure of the Southern Alps, New Zealand, as determined by gravity, in The Origin of the Southern Alps, R. Soc. N. Z. Bull., vol. 18, edited by R. I. Walcott and M. M. Creswell, pp. 95-98.

Wright, T. L. (1991), Structural geology and tectonic evolution of the Los Angeles basin, California, in Active Margin Basins, Am. Assoc. Petrol. Geol. Mem., vol. 52, edited by K. T. Biddle, pp. 35-134.

G. S. Fuis and J. M. Murphy, Earthquake Hazards Team, U.S. Geological Survey, Menlo Park, CA, USA. (fuis@usgs.gov)

M. D. Kohler, Center for Embedded Networked Sensing, University of California, Los Angeles, Calif., USA

M. Scherwath, Leibniz Institute of Marine Sciences, IFMGEOMAR, Kiel, Germany.

U. ten Brink, Coastal and Marine Geology Team, U.S. Geological Survey, Woods Hole, MA, USA.

H. J. A. van Avendonk, Institute of Geophysics, University of Texas, Austin, TX, USA. 
